\title{
Characterization and functional properties of gastric tissue-resident memory $T$ cells from children, adults, and the elderly
}

\section{Jayaum S. Booth ${ }^{1,2+}$, Franklin R. Toapanta ${ }^{1,3 \dagger}$, Rosangela Salerno-Goncalves ${ }^{1,2}$, Seema Patil ${ }^{3,4}$, Howard A. Kader ${ }^{2}$, Anca M. Safta ${ }^{2}$, Steven J. Czinn ${ }^{2}$, Bruce D. Greenwald ${ }^{3,4}$ and Marcelo B. Sztein ${ }^{1,2,3 *}$}

${ }^{1}$ Center for Vaccine Development, University of Maryland School of Medicine, Baltimore, MD, USA

${ }^{2}$ Department of Pediatrics, University of Maryland School of Medicine, Baltimore, MD, USA

${ }^{3}$ Department of Medicine, University of Maryland School of Medicine, Baltimore, MD, USA

${ }^{4}$ Division of Gastroenterology and Hepatology, University of Maryland School of Medicine, Baltimore, MD, USA

\section{Edited by:}

Eric Cox, Ghent University, Belgium

Reviewed by:

Diane Bimczok, University of Alabama at Birmingham, USA

Charles Kelly, King's College London, UK

\section{${ }^{*}$ Correspondence:}

Marcelo B. Sztein, Center for Vaccine Development, University of Maryland School of Medicine, 685 West

Baltimore Street, HSF-1 Room 480,

Baltimore, MD 21201, USA

e-mail: msztein@medicine.

umaryland.edu

${ }^{\dagger}$ Jayaum S. Booth and Franklin R. Toapanta have contributed equally to this work.
T cells are the main orchestrators of protective immunity in the stomach; however, limited information on the presence and function of the gastric $T$ subsets is available mainly due to the difficulty in recovering high numbers of viable cells from human gastric biopsies. To overcome this shortcoming we optimized a cell isolation method that yielded high numbers of viable lamina propria mononuclear cells (LPMC) from gastric biopsies. Classic memory T subsets were identified in gastric LPMC and compared to peripheral blood mononuclear cells (PBMC) obtained from children, adults, and the elderly using an optimized 14 color flow cytometry panel. A dominant effector memory $T$ ( $T_{E M}$ ) phenotype was observed in gastric LPMC CD4 ${ }^{+}$and $\mathrm{CD}^{+} \mathrm{T}$ cells in all age groups. We then evaluated whether these cells represented a population of gastric tissue-resident memory $T\left(T_{\mathrm{RM}}\right)$ cells by assessing expression of CD103 and CD69. The vast majority of gastric LPMC CD8 ${ }^{+}$ T cells either co-expressed CD103/CD69 (>70\%) or expressed CD103 alone ( 20\%). Gastric LPMC CD4 ${ }^{+} \mathrm{T}$ cells also either co-expressed CD103/CD69 (>35\%) or expressed at least one of these markers. Thus, gastric $\mathrm{LPMC} \mathrm{CD}^{+}$and $\mathrm{CD}^{+}{ }^{+} \mathrm{T}$ cells had the characteristics of $\mathrm{T}_{\mathrm{RM}}$ cells. Gastric $\mathrm{CD} 8^{+}$and $\mathrm{CD} 4^{+} \mathrm{T}_{\mathrm{RM}}$ cells produced multiple cytokines (IFN- $\gamma$, IL-2, TNF- $\alpha$, IL-17A, MIP-1 $\beta$ ) and up-regulated CD107a upon stimulation. However, marked differences were observed in their cytokine and multi-cytokine profiles when compared to their PBMCT $T_{E M}$ counterparts. Furthermore, gastric $C D 8^{+} T_{R M}$ and $C D 4^{+} T_{R M}$ cells demonstrated differences in the frequency, susceptibility to activation, and cytokine/multicytokine production profiles among the age groups. Most notably, children's gastric $T_{\text {RM }}$ cells responded differently to stimuli than gastric $T_{\text {RM }}$ cells from adults or the elderly. In conclusion, we demonstrate the presence of gastric $T_{R M}$, which exhibit diverse functional characteristics in children, adults, and the elderly.

Keywords: LPMC, stomach, gastric tissue-resident/memory T cells, multifunctionality

\section{INTRODUCTION}

In human , peripheral blood memory $\mathrm{T}\left(\mathrm{T}_{\mathrm{M}}\right)$ cells are commonly grouped into two major subsets based on their functional status and expression of defined homing receptors (e.g., CD62L, CCR7, and CD45RA) (1): central memory $\mathrm{T}\left(\mathrm{T}_{\mathrm{CM}}\right)$ and effector memory $\mathrm{T}\left(\mathrm{T}_{\mathrm{EM}}\right)$ cells. While $\mathrm{T}_{\mathrm{CM}}$ cells express the lymph node-targeting molecules $\mathrm{CD} 62 \mathrm{~L}$ and CCR7, $\mathrm{T}_{\mathrm{EM}}$ cells largely lack these receptors, and typically express defined homing molecules that endows them with the ability to migrate to peripheral non-lymphoid tissues (1, 2). Recently, a novel population of $\mathrm{T}$ cells known as tissue-resident memory $\mathrm{CD}^{+} \mathrm{T}\left(\mathrm{T}_{\mathrm{RM}}\right)$ cells has been described. These $\mathrm{T}_{\mathrm{RM}}$ cells have the ability to remain for long periods of time in peripheral tissues (e.g., intestinal and vaginal mucosa, skin, brain, and salivary glands) after pathogenic clearance. These cells have been shown to be antigen-specific, express markers of $\mathrm{CD} 8^{+} \mathrm{T}_{\mathrm{EM}}$ cells, and their survival appears to be antigen-independent (3-6). Studies in epithelial and neuronal tissues have shown that $\mathrm{T}_{\mathrm{RM}}$ are characterized by their expression of high levels of $\mathrm{CD} 103$ (the $\alpha$-chain of the integrin $\alpha E \beta 7$ ) and CD69 (a surface molecule typically found on recently activated $\mathrm{T}$ cells) $(7,8)$. While initially described in mice, these cells have been recently also identified in human tissues (9).

The stomach's primary function is to digest food. With its low $\mathrm{pH}$ environment, the stomach has a secondary function in limiting the number of microorganisms that enter the intestinal tract. However, some microorganisms such as Helicobacter pylori ( $H$. pylori) can cause significant pathogenesis and have a niche in this harsh environment. Various immune cells have been identified in stomach biopsies obtained during esophagogastroduodenoscopy (EGD) procedures. Immune populations described in gastric lamina propria mononuclear cells (LPMC) include $\gamma \delta \mathrm{T}$ cells (10), $\mathrm{CD}^{+}{ }^{+}$macrophages $(\mathrm{M} \phi)(\mathrm{M} 1$ and $\mathrm{M} 2)$ (11), dendritic cells (DC) (12), natural killer (NK) (13), NK-T (14), neutrophils, B 
cells (15), and $\mathrm{T}\left(\mathrm{CD}^{+}\right.$and $\left.\mathrm{CD}^{+}\right)$cells $(14,16,17)$. Various studies have demonstrated that intestinal immune cells (innate and adaptive) are phenotypically and functionally different from their systemic counterparts. For example, intestinal $M \phi$ is more phagocytic and bactericidal but secrete less pro-inflammatory cytokines than their peripheral blood counterparts (18). Additionally, the $\mathrm{CD} 4^{+} / \mathrm{CD} 8^{+}$ratio is inverted $(\sim 1: 3)$ in gastric LPMC (from healthy volunteers) compared to peripheral blood mononuclear cells (PBMC) $(\sim 3: 1)(16,19,20)$. Despite these observations, very little is known about the different $\mathrm{T}$ cell subsets present in the gastric mucosa of healthy humans. For example, it is currently unknown whether $\mathrm{T}_{\mathrm{CM}}$ and $\mathrm{T}_{\mathrm{EM}}$ cells have similar percentage distribution in the gastric mucosa as in peripheral blood. Furthermore, despite that the acidic environment of the stomach provides a different environment than the one found in the mucosa of the small and large intestines, the gastric mucosa is part of the digestive tract and therefore has the potential to harbor $\mathrm{T}_{\mathrm{RM}}$ cells. However, the presence of $\mathrm{T}_{\mathrm{RM}}$ cells and their ability to exhibit effector functions (e.g., cytokine production and cytotoxicity) is currently unknown. In addition, no study has assessed the frequency of these cells in the gastric mucosa and differences in various age groups (children, adults, and the elderly). In the present study, after optimizing an isolation method for LPMC from gastric biopsies, we characterized in depth the memory $\mathrm{CD}^{+}{ }^{+}$and $\mathrm{CD} 8^{+} \mathrm{T}$ cell subsets in gastric LPMC of healthy human volunteers. We demonstrated that the most abundant $\mathrm{CD}^{+} \mathrm{T}$ cell population in the stomach $(>80 \%)$ was $\mathrm{T}_{\mathrm{RM}}\left(\mathrm{CD} 6 \mathrm{~L}^{-}, \mathrm{CD} 45 \mathrm{RA}^{-}, \mathrm{CD} 103^{+}\right.$, and $\left.\mathrm{CD}^{+} 9^{+}\right)$. These cells were able to produce various cytokines (either single or multiple cytokines simultaneously) when stimulated with mitogens and demonstrated differences in the strength and quality of the responses among different age groups (adults, children, and the elderly). These findings were only partially mirrored by gastric $\mathrm{CD}^{+}{ }^{+} \mathrm{T}_{\mathrm{RM}}$ cells, since only $\sim 35 \%$ of the cells showed coexpression of CD103 and CD69. However, these cells were also able to produce cytokines and showed differences among the age groups evaluated. These novel findings suggest that $\mathrm{T}_{\mathrm{RM}}$ might play a key role in protection from gastric infections and offer new insights into age differences in gastric immunity.

\section{MATERIALS AND METHODS \\ VOLUNTEERS AND ISOLATION OF PERIPHERAL BLOOD MONONUCLEAR CELLS}

Volunteers were recruited from the Baltimore-Washington area and University of Maryland, Baltimore campus. Written informed consent was obtained and all procedures were approved by the University of Maryland, Baltimore IRB. Immediately after blood draws, PBMC were isolated by density gradient centrifugation and used freshly for stimulation and characterization. Blood and gastric biopsies were collected at the same time. A total of 57 volunteers (aged 7-85 years) were evaluated.

\section{ISOLATION OF LAMINA PROPRIA MONONUCLEAR CELLS}

Gastric biopsies were collected from volunteers ( $7-85$ years-old) referred for outpatient diagnostic upper endoscopy (EGD) at the University of Maryland Medical Center. The indications for EGD included abdominal pain, heartburn, GERD, dysphagia, and acute gastritis. Diagnostic pathology reports showed that the stomach's antrum mucosa was either normal $(n=12)$ or exhibited mild inflammation $(n=45)$. No concurrent GI disease/disorders or other illnesses that may affect the GI tract were present. Additionally, all volunteers were confirmed to be $H$. pylori negative as determined by culture and rapid Urease test (CLO test).Tissue samples collected during EGD were transported to the laboratory facilities in a tube containing RPMI 1640 (Gibco, Carlsbad, CA, USA) with antibiotics/antifungal (Penicillin/Streptomycin/Amphotericin B; Gibco) and processed immediately after collection as shown in Figure 1 and Figure S1 in Supplementary Material. We first compared two methods the isolation of gastric LPMC: (i) a conventional method (CM) and (ii) bullet blender (BB) method. The CM method consisted of three steps: (a) removal of intraepithelial lymphocytes (IEL) [HBSS + EDTA $(1 \mathrm{mM})]$, (b) digestion of the resulting tissues (collagenase D/DNase I), and (c) disaggregation of the tissues (by teasing of the tissues between the frosty ends of two microscope glass slides). The BB method also consisted of three steps. The first two steps were similar to the CM whist the last step consisted of homogenizing the gastric biopsy tissues using a BB (Next Advance, Averill Park, NY, USA) (Figure 1). To perform these methods, media was removed from the biopsies by using a $70-\mu \mathrm{m}$ cell strainer (BD Falcon, Franklin Lakes, NJ, USA) and dried through the filter using sterile gauze. The tissue was then transferred to a pre-weighted $1.5 \mathrm{ml}$ centrifuge tube and the net weight measured. Biopsies were then rapidly transferred to a $50 \mathrm{ml}$ conical tube containing $10 \mathrm{ml}$ of $\mathrm{HBSS}$ without $\mathrm{CaCl}_{2}$, $\mathrm{MgCl}_{2}, \mathrm{MgSO}_{4}$ (Gibco) with antibiotics/antifungal mix (Gibco) and EDTA $(1 \mathrm{mM})$ and incubated at $37^{\circ} \mathrm{C}$ for $30 \mathrm{~min}$ while shaking. The tissues were washed with $10 \mathrm{ml}$ of HBSS buffer (with $\mathrm{CaCl}_{2}, \mathrm{MgCl}_{2}$ ) (Gibco) without EDTA and incubated for $10 \mathrm{~min}$ at room temperature (RT) while shaking. The tissues were then enzymatically digested either in six well plates (CM method) or $1.5 \mathrm{ml}$ sterile screw-top polypropylene microcentrifuge tubes (BB method) containing $1 \mathrm{ml}$ of digestion solution. Tubes used for the BB method also contained two stainless steel beads $(3.2 \mathrm{~mm}$ 
diameter; Next Advance Inc., Averill, NY, USA). The enzymatic digestion solution consisted of $1 \mathrm{ml}$ of RPMI containing $10 \mu \mathrm{l}$ of fetal bovine serum (FBS) (Gemini Bioproducts, West Sacramento, CA, USA), $10 \mu \mathrm{l}$ antibiotics/antifungal mix (Gibco), $10 \mu \mathrm{l}$ of $2.5 \mathrm{M} \mathrm{CaCl}_{2}, 10 \mu \mathrm{l}$ of Collagenase D $(100 \mu \mathrm{g} / \mathrm{ml}$; Roche, Indianapolis, IN, USA), and $1 \mu \mathrm{l}$ DNase I $(10 \mu \mathrm{g} / \mathrm{ml}$; Affymetrix, Cleveland, $\mathrm{OH}, \mathrm{USA}$ ). The biopsies (20 $\mathrm{mg}$ maximum per tube) were digested for $45 \mathrm{~min}$ at $37^{\circ} \mathrm{C}$ with intermittent pipetting (CM method) or shaking (BB method). Following $45 \mathrm{~min}$ incubation, the tissues were disaggregated using the frosty ends of glass slides (CM method). In the case of the $\mathrm{BB}$ method, following the 45 min digestion the tube was placed in a $\mathrm{BB}$ homogenizer (Next Advance Inc., NY, USA) and the tissue homogenized for $30 \mathrm{~s}$ (speed 1). Tissues were further incubated for $15 \mathrm{~min}\left(37^{\circ} \mathrm{C}\right)$. After the second digestion by either method, cells were collected in a $50 \mathrm{ml}$ tube through a $70 \mu \mathrm{m}$ cell strainer and centrifuged at $1400 \mathrm{rpm}$. Cells were then washed and re-suspended in complete RPMI [Heat inactivated FBS (10\%), L-glutamine ( $2 \mathrm{mM})$, non-essential Amino acids (1×) (Gibco 11140), HEPES buffer (10 mM) (Gibco 15630-080), Sodium pyruvate (2.5 mM) (Lonza 13-155E), Penicillin/streptomycin (100 U/ml-100 $\mu \mathrm{g} / \mathrm{ml}$ ) (Sigma P0781), Gentamicin (50 $\mu \mathrm{g} / \mathrm{ml})$ (Gibco 15750-060)], and counted using Kova Glasstic Slides (Hycor Biomedical, CA, USA). Cells were either stained immediately for immunophenotyping by flow cytometry or stimulated with mitogens overnight before staining (see below). To evaluate whether the enzymatic digestion resulted in loss of surface receptors, PBMC were either treated or untreated with the same digestion mix and processed as detailed above and assessed for surface markers (Figures S1C,D in Supplementary Material). To determine the effect of collagenase D in the digestion mix on surface marker expression the above procedure was followed using an enzymatic mix in which collagenase D was replaced with dispase $(1 \mu \mathrm{g} / \mathrm{ml})$ (Figure S1C in Supplementary Material).

\section{FLOW CYTOMETRY PROCEDURES AND STAINING Ex vivo stimulation}

Freshly isolated cells from PBMC and gastric biopsies (LPMC) were re-suspended in complete media and stimulated with medium, staphylococcal enterotoxin B (SEB) $(10 \mu \mathrm{g} / \mathrm{ml}$; Sigma) or Dynabeads Human T activator CD3/CD28 $\left(4 \times 10^{4}\right.$ beads $\left./ \mathrm{ml}\right)$ (Invitrogen Dynal, Oslo, Norway). For each treatment, $1 \times 10^{5}$ LPMC and $1 \times 10^{6}$ PBMC were cultured in $200 \mu \mathrm{l}$ and $1 \mathrm{ml}$ total volumes, respectively, and incubated at $37^{\circ} \mathrm{C}$ in $5 \% \mathrm{CO}_{2}$. In some experiments, cells were stained with CD107a-FITC at the time of stimulation. After $2 \mathrm{~h}$, GolgiStop (Monensin, BD) and GolgiPlug (Brefeldin A, BD) were added at concentrations of $0.5 \mu \mathrm{l} / \mathrm{ml}$ and cultures continued overnight at $37^{\circ} \mathrm{C}$ in $5 \% \mathrm{CO}_{2}$.

\section{Surface and intracellular staining}

Following stimulation, PBMC and LPMC were plated in 96well V-bottom plates for staining. Cells were washed twice with phosphate buffered saline (PBS) and stained for live/dead discrimination using Invitrogen LIVE/DEAD fixable yellow dead cell stain kit (YEVID) (Invitrogen, Carlsbad, CA, USA). Blocking of Fc receptors was performed using human immunoglobulin ( $3 \mu \mathrm{g} / \mathrm{ml}$; Sigma) and was followed by surface staining, performed as previously described (21). Briefly, cells were stained with fluorescently labeled monoclonal antibodies (mAbs) directed to CD14-BV570 (clone M5E2, Biolegend, San Diego, CA, USA) and CD19-BV570 (clone HIB19, Biolegend), CD3-BV650 (clone OKT3, Biolegend), CD4-PE-Cy5 (clone RPA-T4, BD), CD8PerCP-Cy5.5 (clone SK-1, Becton-Dickinson, BD), CD45RAbiotin (clone HI100, BD), integrin $\alpha 4 \beta 7$-Alexa Fluor 647 (clone Act-1, Leukosite, Cambridge, MA, USA), and CD62L-Alexa Fluor 780 (clone DREG-5, eBioscience, San Diego, CA, USA) at $4^{\circ} \mathrm{C}$ for $30 \mathrm{~min}$. Staining with streptavidin-QDot800 (Invitrogen) was performed for panels that included biotin-conjugated mAbs for $30 \mathrm{~min}$ at $4^{\circ} \mathrm{C}$. The cells were then fixed and permeabilized using IC fixation and permeabilization buffers (eBioscience) according to the manufacturer's recommendations. Intracellular staining with mAbs to IL-17A-BV421 (clone BL168, Biolegend), IL-2-BV605 (clone MQ1-17H12, Biolegend), IFN- $\gamma$-PE-Cy7 (clone B27, BD), TNF- $\alpha$-Alexa 700 (clone MAb11, BD), MIP-1 $\beta$-PE (clone 24006, R\&D Systems, Minneapolis, MN, USA), and CD69-ECD (clone TP1.55.3, Beckman Coulter, Danvers, MA, USA) was performed at $4^{\circ} \mathrm{C}$ overnight. After staining, cells were fixed in $1 \%$ paraformaldehyde and stored at $4^{\circ} \mathrm{C}$ until data collection. Data were collected using a customized LSRII flow cytometer (BD) and then analyzed using WinList version 7 (Verity Software House, Topsham, ME, USA) software package. Graphs were generated using GraphPad Prism version 5.03 (GraphPad Software, San Diego, CA, USA).

In experiments designed to characterize $\mathrm{T}_{\mathrm{RM}}$ cells, the staining panels were modified as follows. LPMC and PBMC were stained with mAbs directed to CD103-Alexa Fluor 488 (clone Ber-ACT8, Biolegend), CD14-BV570 (clone M5E2, Biolegend, San Diego, CA, USA), CD13-Pacific Orange (clone WM-15 eBioscience, San Diego, CA, USA conjugated to Pacific Orange in-house), CD19-BV570 (clone HIB19, Biolegend), CD3-BV650 (OKT3, Biolegend), CD4-PE-Cy5 (clone RPA-T4, BD), CD8-PerCP-Cy5.5 (clone SK-1, BD), CD45RA-biotin (clone HI100, BD), integrin $\alpha 4 \beta 7$-Alexa Fluor 647 (clone Act-1, Leukosite, Cambridge, MA, USA), and CD62L-Alexa Fluor 780 (clone DREG-5, eBioscience, San Diego, CA, USA) and intracellularly with mAbs to IL-17ABV421 (clone BL168, Biolegend), IL-2-BV605 (clone MQ1-17H12, Biolegend), IFN- $\gamma$-PE-Cy7 (clone B27, BD), TNF- $\alpha$-Alexa 700 (clone MAb11, BD), MIP-1 $\beta$-PE (clone 24006, R\&D systems, Minneapolis, MN, USA), and CD69-ECD (clone TP1.55.3, Beckman Coulter, Danvers, MA, USA).

\section{FCOM ANALYSIS FOR MULTIFUNCTIONALITY}

FCOM (Verity Software House, Topsham, ME, USA) is an analytical tool that is used to classify events based on combinations of selected gates. FCOM reduces multiparameter data to a series of multiple acquisition gates, one for every possible combination. FCOM was employed to determine the subsets of $\mathrm{CD}^{+}$and $\mathrm{CD}^{+}$producing multiple cytokines and/or expressing CD107a expression (i.e., multifunctionality).

\section{STATISTICAL ANALYSIS}

Data were analyzed using GRAPHPAD PRISM ${ }^{\mathrm{TM}} 5.03$ statistical software (Graphpad, San Diego, CA, USA). Statistical differences in median values between two groups were determined using Mann-Whitney tests. Statistical differences between multiple 
groups (more than two) were determined by Kruskal-Wallis tests and the Dunn's post-test was used to compare selected group pairs. Values of ${ }^{\star} p<0.05,{ }^{* *} p<0.005,{ }^{* *} p<0.0005$ were considered significant.

\section{RESULTS}

\section{GASTRIC LPMC ISOLATION AND CELL YIELDS FROM CHILDREN, ADULTS, AND ELDERLY VOLUNTEERS}

Several methodologies to isolate gastric leukocytes from human stomach biopsies have been reported; however, there is a lack of consensus in the type of digestion enzymes to use, their concentration, digestion periods and whether or not to use mechanical dissociation techniques. Therefore, we optimized a protocol for isolation of gastric LPMC. We first compared two methods: (i) a conventional method (CM) and (ii) a blender method (BB) (described in detail in Section "Materials and Methods"). In the BB method, we optimized the homogenization step regarding the speed, time, and number of beads needed for a gentle dissociation of the cells from the gastric tissues. We found that homogenizing the tissue for $30 \mathrm{~s}$ at a speed of 1 and using 2 beads (stainless steel; $3.2 \mathrm{~mm}$ diameter) resulted in optimal cell yields (Figure S1A in Supplementary Material). This optimized BB method yielded superior cell numbers $\left(1.1 \times 10^{4} / \mathrm{mg}\right.$ of tissue $)$ from human biopsies compared to the CM method $\left(0.6 \times 10^{4} / \mathrm{mg}\right.$ of tissue) (Figure $\mathrm{S} 1 \mathrm{~B}$ in Supplementary Material). Two digestion enzymes (collagenase $\mathrm{D}$ and dispase) were then compared by substituting each one using the optimized $\mathrm{BB}$ method. We observed that collagenase $\mathrm{D}$ treatment resulted in better cell yields and cell surface marker preservation than dispase, which had a marked effect on the expression of cell surface markers as shown by lower MFI for $\mathrm{CD}^{+}$and $\mathrm{CD}^{+}{ }^{+} \mathrm{T}$ cells in both PBMC and LPMC isolated cells (Figure S1C in Supplementary Material). We further evaluated the effect of collagenase D on tissues by using PBMC treated in similar fashion as biopsies with the BB method. The results showed no significant differences in the expression levels of CD3, CD4, CD8, CD45RA, CD62L, and integrin $\alpha 4 \beta 7$ surface markers between PBMC treated with or without collagenase D (Figure S1D in Supplementary Material).

Stomach biopsies (antrum) obtained from $H$. pylori negative (CLO test negative) adult (18-64 years), children ( $7-17$ years), and elderly (65-85 years) volunteers were processed as described in Section "Materials and Methods" and Figure 1. Gastric LPMC were isolated and enumerated from five biopsy samples from each adult and elderly volunteer and three biopsy samples from each child (Figure 2A). The viable cell yields in biopsies from adult and the elderly ranged from 230,000 to 2,300,000 (median 634,000) and 240,000 to $1,300,000$ (median 605,000 ) cells, respectively; whereas in children's biopsies cell yields ranged from 320,000 to 734,000 (median: 492,000) cells (Figure 2A). The total viable cell yields in the children group was significantly lower $(p<0.05)$ than in the adult group. However, the weight of biopsies varied between age groups as samples from children were significantly $(p<0.05)$ smaller in size and weight $(8.8-33.4 \mathrm{mg})$ than samples from adults $(20.5-76 \mathrm{mg})$ and the elderly $(31.7-51.9 \mathrm{mg}$ ) (Figure 2A). To compare the viable cell yields among age groups we calculated the number of viable cells per milligram of tissue. The results showed that the cell yields obtained from biopsies of children (13,000-49,000 viable cells/mg of tissue, median: 21,000) were significantly higher $(p<0.05)$ than those obtained from biopsies of the elderly (6000-49,000, median: 15,500) (Figures 2A,B).

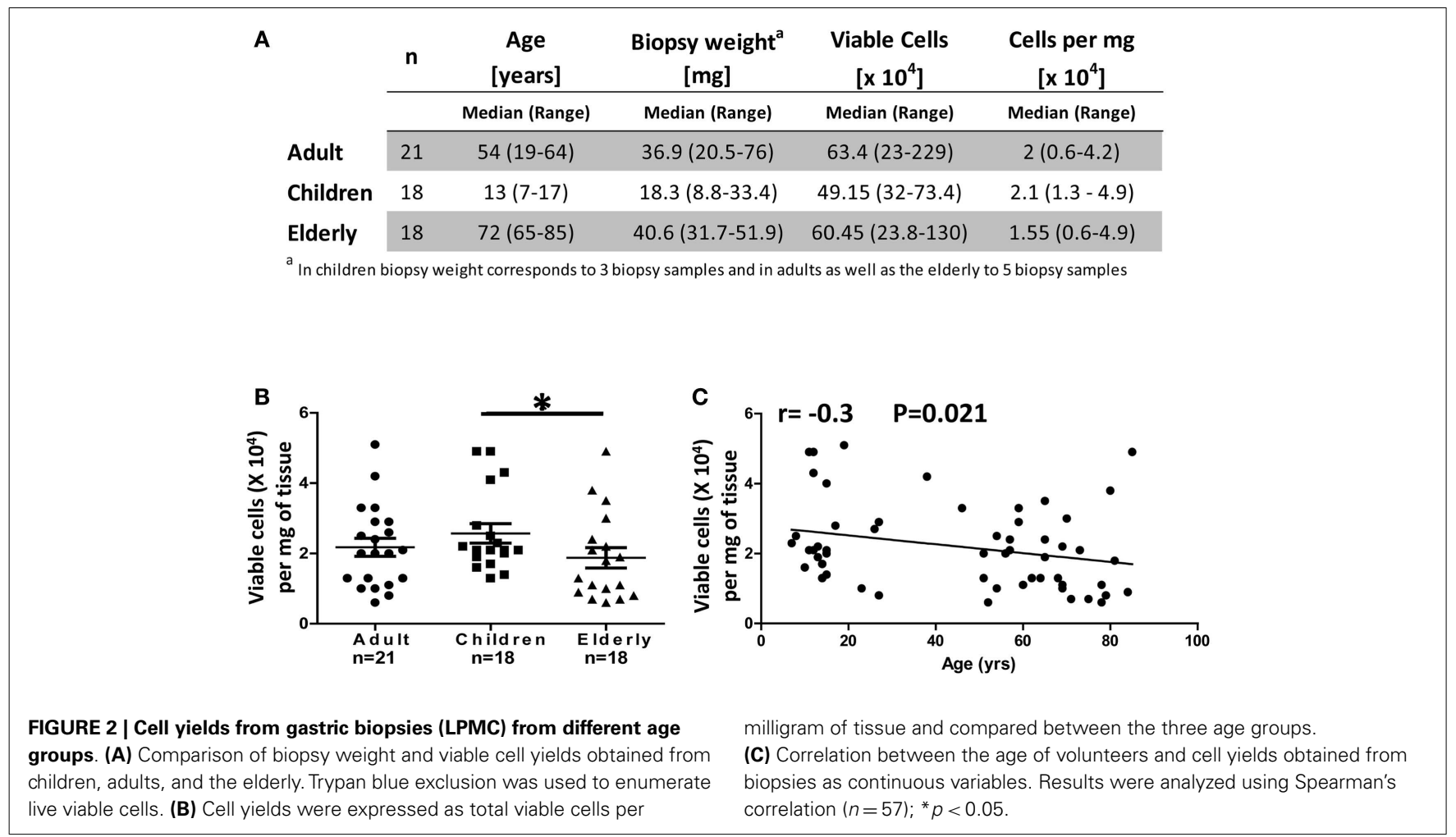


Finally, using Pearson's regression analysis, we observed a significant inverse correlation $(r=-0.3, p=0.021)$ between the number of isolated cells per milligram of tissue and age (Figure 2C).

\section{CHARACTERIZATION OF T CELL SUBSETS IN LPMC AND PBMC}

Human gastric $\mathrm{T}$ lymphocytes have been shown to display a Th1 type response (IFN- $\gamma$, TNF- $\alpha$, and IL-2 secretion) toward pathogens, such as $H$. pylori (16). However, the $\mathrm{T}_{\mathrm{M}}$ subset(s) that secrete(s) these cytokines and differences among the various age groups have not been explored. To address these shortcomings, the presence of $\mathrm{T}$ cells $\left(\mathrm{CD}^{+}{ }^{+} \mathrm{CD} 13^{-} \mathrm{CD}^{-}{ }^{-}\right)$in $\mathrm{LPMC}$ and PBMC was assessed (Figure 3A). The frequency of these cells was significantly lower in LPMC than in PBMC from adult volunteers (median: 13.7 vs. $74.7 \%$; $p<0.0005$ ) (Figures 3A,B). Similar findings were observed in children and the elderly (Figure 3B). When $\mathrm{CD}^{+}{ }^{+} \mathrm{T}$ cells were divided into $\mathrm{CD}^{+}{ }^{+}\left(\mathrm{CD}^{+}{ }^{+} \mathrm{CD} 4^{+}\right)$and $\mathrm{CD} 8^{+}$ $\left(\mathrm{CD}^{+}{ }^{+} \mathrm{CD}^{+}\right) \mathrm{T}$ cells, the latter were more abundant in LPMC than in PBMC (Figures 3A,B). Therefore, there was an inversion in the CD4/CD8 ratio in LPMC $(\sim 1: 3)$ compared to PBMC $(\sim 3: 1)$. These results confirmed and extended those reported by others $(16,19,20)$ by showing that these differences were observed in all age groups (Figure 3B). When $\mathrm{CD}^{+}{ }^{+} \mathrm{T}$ cells in LPMC of children and the elderly were compared to adults, children showed a significantly higher frequency of these cells (Figure 3B). In contrast, PBMC from all three groups expressed similar levels of $\mathrm{CD}^{+}, \mathrm{CD}^{+}$, and $\mathrm{CD}^{+}{ }^{+} \mathrm{T}$ cells (Figure 3B). Next, we evaluated the presence of $\mathrm{T}_{\mathrm{M}}$ cells in LPMC and PBMC using CD62L and
CD45RA markers. These markers define four different subsets: (i) $\mathrm{T}$ central memory $\left(\mathrm{T}_{\mathrm{CM}}\right)\left(\mathrm{CD} 2 \mathrm{~L}^{+} \mathrm{CD} 45 \mathrm{RA}^{-}\right)$, (ii) $\mathrm{T}$ naïve ( $\left.\mathrm{T}_{\text {naive }}\right)\left(\mathrm{CD} 2 \mathrm{~L}^{+} \mathrm{CD} 45 \mathrm{RA}^{+}\right)$, (iii) $\mathrm{T} \mathrm{T}_{\mathrm{EM}}\left(\mathrm{CD} 62 \mathrm{~L}^{-} \mathrm{CD}^{-} 4 \mathrm{RA}^{-}\right)$, and (iv) CD45RA positive $\mathrm{T} \mathrm{T}_{\mathrm{EMRA}}\left(\mathrm{CD} 2 \mathrm{~L}^{-} \mathrm{CD}^{-} 5 \mathrm{RA}^{+}\right.$) (22). Interestingly, the vast majority of adult $\mathrm{CD}^{+}$and $\mathrm{CD} 4^{+} \mathrm{T}$ cells in LPMC showed a $\mathrm{T}_{\mathrm{EM}}$ phenotype $(>70 \%)\left(\mathrm{CD}^{-} \mathrm{L}^{-}, \mathrm{CD} 4 \mathrm{RA}^{-}\right)$ (Figures 3A,B). This phenotype was also dominant in children and the elderly (Figure 3B). In contrast, the classic memory $\left(\mathrm{T}_{\mathrm{CM}}, \mathrm{T}_{\mathrm{EM}}\right.$, and $\mathrm{T}_{\text {EMRA }}$ ) and naïve subsets defined by CD62L and CD45RA were identified in PBMC (Figures 3A,B). The finding that LPMC $\mathrm{CD}^{+}$and $\mathrm{CD}^{+} \mathrm{T}$ cells showed a dominant $\mathrm{T}_{\mathrm{EM}}$ phenotype suggested that these cells could represent a population of gastric tissue-resident memory $\mathrm{T}\left(\mathrm{T}_{\mathrm{RM}}\right)$ cells. The hallmark of $\mathrm{T}_{\mathrm{RM}}$ is the surface expression of high levels of CD103 and CD69 (4, 68); therefore, we evaluated expression of these markers in LPMC and PBMC. We observed that most $\mathrm{CD}^{+}{ }^{+} \mathrm{T}$ cells in LPMC coexpressed CD103 and CD69 (mean: 81.1\%; median: 80.5\%), while a much lower percentage of $\mathrm{CD}^{+}{ }^{+} \mathrm{T}$ cells in LPMC co-expressed these markers (mean: 35\%; median: 28.8\%) (Figures 3C,D). Similar results were observed in all the volunteers tested (Figure 3D). On the other hand, CD103 and CD69 were virtually absent from $\mathrm{CD}^{+}$and $\mathrm{CD}^{+}$T cells in PBMC. Further analysis revealed that $\mathrm{CD}^{+} \mathrm{T}$ cells in LPMC either co-expressed CD103 and CD69 $(>70 \%)$ or expressed CD103 alone ( 20\%); therefore, more than $90 \%$ of these cells expressed at least one marker that defined them as $\mathrm{T}_{\mathrm{RM}}$ cells (Figure $3 \mathrm{C}$ ). Similarly, even though only $\sim 30 \%$ of $\mathrm{CD}^{+}{ }^{+} \mathrm{T}$ cells in LPMC co-expressed CD103 and CD69, expression

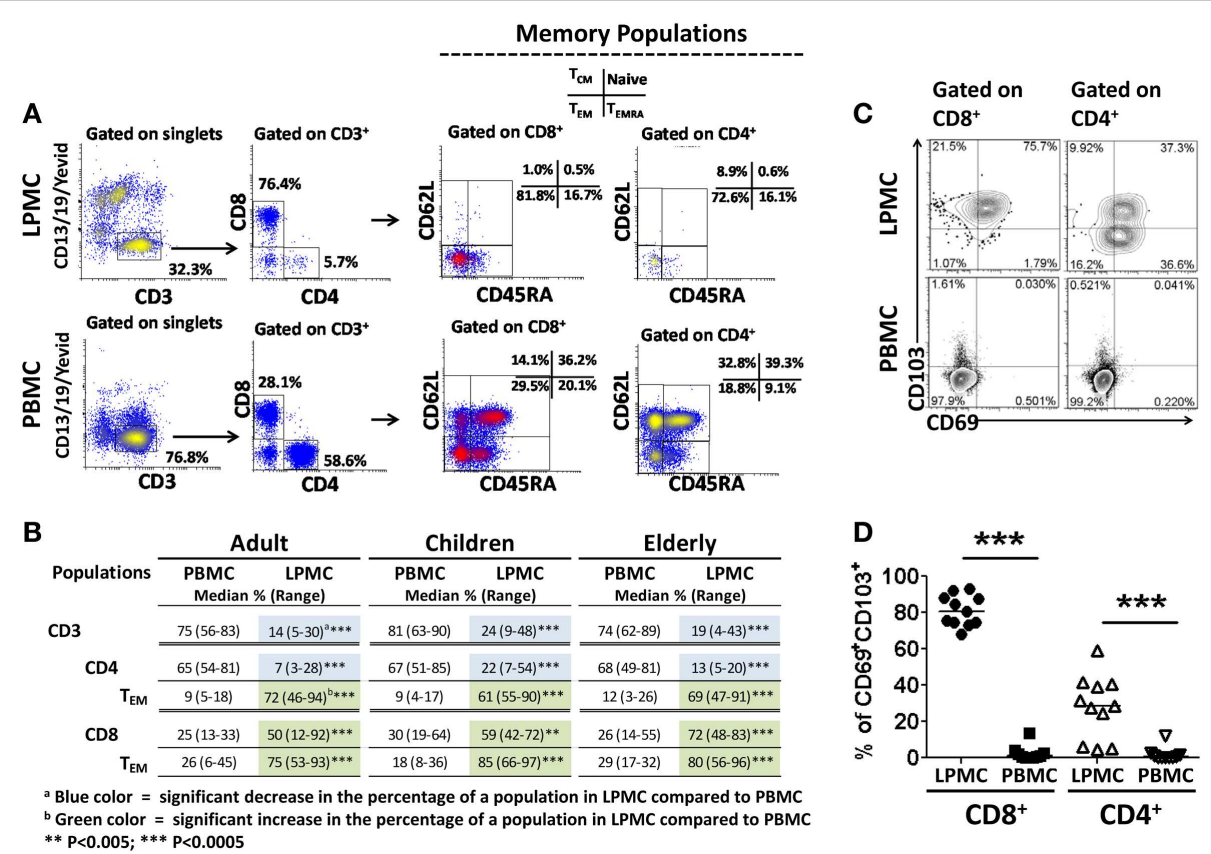

FIGURE 3 | Characterization of memory $\mathrm{T}\left(\mathrm{T}_{\mathrm{M}}\right)$ cells in gastric LPMC and PBMC from children, adults, and the elderly. (A) Representative scatter plots of the gating strategy used to characterize $T$ cell subsets in $L P M C$ and PBMC: naïve (CD62 $\left.\mathrm{L}^{+} \mathrm{CD} 45 \mathrm{RA}^{+}\right)$, central memory $\left(\mathrm{T}_{\mathrm{CM}}, \mathrm{CD} 6 \mathrm{~L}^{+} \mathrm{CD} 45 \mathrm{RA}^{-}\right)$, effector memory ( $\left.T_{E M}, C D 62 L^{-} C D 45 R A^{-}\right)$, and effector memory expressing CD45RA ( $T_{\text {EMRA }}, C$ 62 $L^{-}$CD45RA ${ }^{+}$). Data shown are from a 12 year-old child. (B) Cumulative data showing the median \% and range of $\mathrm{CD} 3, \mathrm{CD} 4, \mathrm{CD} 8, \mathrm{~T}_{\mathrm{EM}}$ populations in gastric LPMC and PBMC from all three age groups. (C) Identification of tissue-resident memory $T\left(T_{\mathrm{RM}}\right)$ cells in gastric LPMC. Representative plots showing expression of $\mathrm{T}_{\mathrm{RM}}$ cells as defined by the concomitant expression of CD103 and CD69 markers on $\mathrm{CD}^{+}$and $\mathrm{CD} 4^{+} \mathrm{T}$ cells in gastric LPMC and PBMC. (D) Cumulative data $(n=10)$ showing the percentage of gastric $T_{\mathrm{RM}}$ cells among $\mathrm{CD}^{+}$and $\mathrm{CD}^{+}{ }^{+} \mathrm{T}$ cells from $\mathrm{LPMC}$ and PBMC $\left({ }^{* * *} p<0.0005\right)$. 
of CD69 or CD103 alone was found in 35 and $~ 10 \%$ of these cells, respectively. In sum, the majority of the $\mathrm{CD}^{+}$and $\mathrm{CD}^{+} \mathrm{T}$ cells in LPMC expressed molecules compatible with those reported for $\mathrm{T}_{\mathrm{RM}}$ cells. In contrast, the expression of CD103 and CD69 was virtually absent from PBMC CD4 ${ }^{+}$and $\mathrm{CD}^{+}{ }^{+} \mathrm{T}$ cells (Figures $3 \mathrm{C,D}$ ). Expression of the homing marker integrin $\alpha 4 \beta 7$ was assessed in PBMC and LPMC in the subsets showing the $\mathrm{T}_{\mathrm{EM}}$ phenotype $\left(\mathrm{T}_{\mathrm{RM}}\right.$ in LPMC and $\mathrm{T}_{\mathrm{EM}}$ in PBMC) (Figure 4A). Gastric CD8 ${ }^{+} \mathrm{T}_{\mathrm{RM}}$ and $\mathrm{CD} 4{ }^{+} \mathrm{T}_{\mathrm{RM}}$ showed a significantly lower level of expression of integrin $\alpha 4 \beta 7(p<0.05)$ compared to $\mathrm{CD} 8^{+} \mathrm{T}_{\mathrm{EM}}$ and $\mathrm{CD} 4^{+} \mathrm{T}_{\mathrm{EM}}$ (Figures 4A,B). Interestingly, there were no significant differences in integrin $\alpha 4 \beta 7$ expression among gastric LPMC CD8 ${ }^{+} \mathrm{T}_{\mathrm{RM}}$ or $\mathrm{CD}^{+}{ }^{+} \mathrm{T}_{\mathrm{RM}}$ between adult, children, and the elderly (Figure $4 \mathrm{C}$ ).

\section{MITOGEN ACTIVATION OF LPMC AND PBMC}

We next examined whether isolated gastric $\mathrm{LPMC} \mathrm{CD}^{+}$or $\mathrm{CD} 4^{+}$ $\mathrm{T}_{\mathrm{RM}}$ cells were functionally active by exploring whether they responded to mitogen stimulation by producing cytokines and upregulating the expression of CD107a, a marker of degranulation associated with cytotoxic activity (23). Furthermore, we explored whether there were any differences in the responses between the different age groups. Gastric LPMC and PBMC were stimulated with various $\mathrm{T}$ cell stimulants including: (i) SEB (superantigen) and (ii) $\alpha$-CD3/CD28 coated beads (TCR stimulation). As negative control, cells were incubated in media alone. The concomitant production of multiple cytokines (IFN- $\gamma$, TNF- $\alpha$, IL-2, IL-17A, and MIP-1 $\beta$ ) and up-regulation of CD107a were determined in
LPMC (Figures 5A,B) and PBMC in all three age groups. Upregulation of $\mathrm{CD} 69$ as a cell activation marker was only considered for PBMC since in LPMC ( $\left.\mathrm{T}_{\mathrm{RM}}\right)$ this marker is highly expressed regardless of stimulation (Figures $3 C, D$ ). In PBMC, the main $T_{M}$ subsets responding to the stimulations were $\mathrm{CD} 8^{+}$and $\mathrm{CD} 4^{+}$ $\mathrm{T}_{\mathrm{EM}}$ and $\mathrm{T}_{\mathrm{EMRA}}$ and these results were consistent with previous reports from our group, as well as others $(6,24)$. The percentages of gastric $\mathrm{CD} 8^{+} \mathrm{T}_{\mathrm{RM}}$ and $\mathrm{CD} 4^{+} \mathrm{T}_{\mathrm{RM}}$ producing cytokines and up-regulating CD107a following stimulation were compared to $\mathrm{CD}^{+} \mathrm{T}_{\mathrm{EM}}$ and $\mathrm{CD} 4^{+} \mathrm{T}_{\mathrm{EM}}(\mathrm{PBMC})$ and the results in all age groups are summarized in Tables $\mathbf{1 - 4}$.

Interestingly, control media gastric $\mathrm{CD} 8^{+}$and $\mathrm{CD} 4^{+} \mathrm{T}_{\mathrm{RM}}$ cells from adult volunteers showed higher percentages of cells producing cytokines and up-regulating expression of CD107a than media only $\mathrm{CD}^{+} \mathrm{T}_{\mathrm{EM}}$ and CD4 ${ }^{+} \mathrm{T}_{\mathrm{EM}}$ (PBMC) cells (Figures $5 \mathrm{C}, \mathrm{D}$ ). This difference in baseline cytokine production was statistically significant $(p<0.05)$ only in $\mathrm{CD}^{+} \mathrm{T}$ cells (Figures $5 \mathrm{C}, \mathrm{D}$ ). Of note, in children, while higher $\mathrm{CD}^{+} \mathrm{T}_{\mathrm{RM}}$ cells producing cytokines and up-regulating the expression of CD107a were observed, no statistically significant differences were found compared to $\mathrm{CD} 8^{+} \mathrm{T}_{\mathrm{EM}}$ cells in media controls (Table 1). In the elderly group, a percentage of cells producing significant higher baseline levels of IL- 2 and MIP- $1 \beta$ in gastric $\mathrm{CD} 8^{+} \mathrm{T}_{\mathrm{RM}}$ cells were identified. Concerning the other cytokines investigated, as well as CD107a, although a similar trend to the other age groups was observed, the differences did not reach statistical significance, likely due to high subject-to-subject variability (Table 1). Additionally,
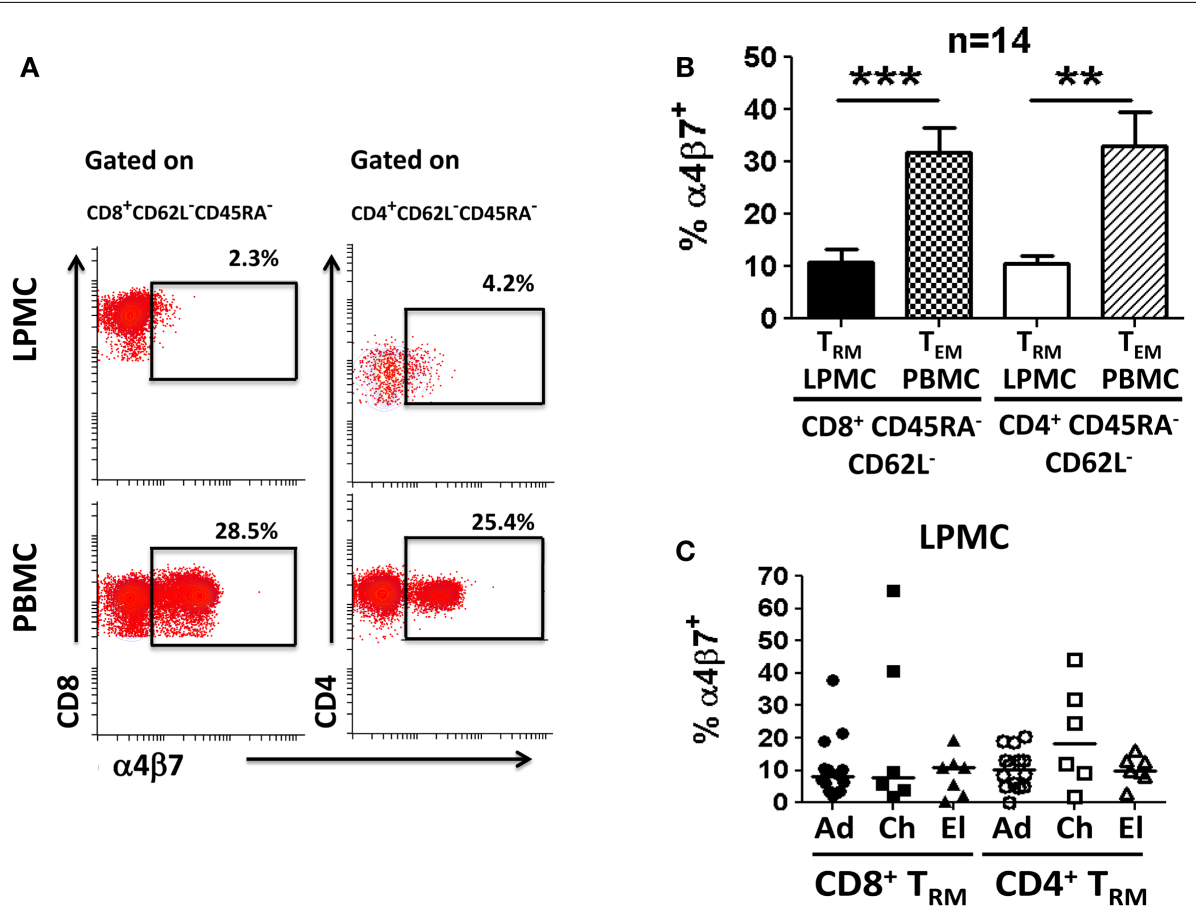

FIGURE 4 | Characterization of integrin $\alpha 4 \beta 7$ expression on memory $T$ ( $T_{R M}$ and $T_{E M}$ ) cells in gastric LPMC and PBMC. (A) Representative scatter plots showing integrin $\alpha 4 \beta 7$ expression on $\mathrm{CD} 8^{+}$and $\mathrm{CD} 4^{+}$gastric $\mathrm{LPMC}$ and PBMC (data shown are from a 12-year-old child). (B) Cumulative data $(n=14)$ showing the percentage of $\mathrm{CD}^{+}$and $\mathrm{CD} 4^{+} \mathrm{T}_{\mathrm{RM}}(\mathrm{LPMC})$ as well as $\mathrm{CD} 8^{+}$and

$\mathrm{CD}^{+} \mathrm{T}_{\mathrm{EM}}(\mathrm{PBMC})$ cells expressing integrin $\alpha 4 \beta 7$. Significant differences are denoted as follows: ${ }^{*} p<0.005 ;{ }^{* * *} p<0.0005$. (C) Cumulative data comparing the percentage of $\mathrm{CD}^{+}$or $\mathrm{CD}^{+} \mathrm{T}_{\mathrm{RM}}$ subsets (LPMC) expressing integrin $\alpha 4 \beta 7$ by age group. Closed and open symbols represent $\mathrm{CD} 8^{+}$and $\mathrm{CD}^{+} \mathrm{T}_{\mathrm{RM}}$ cells, respectively: adults (Ad); children (Ch); elderly (EI). 


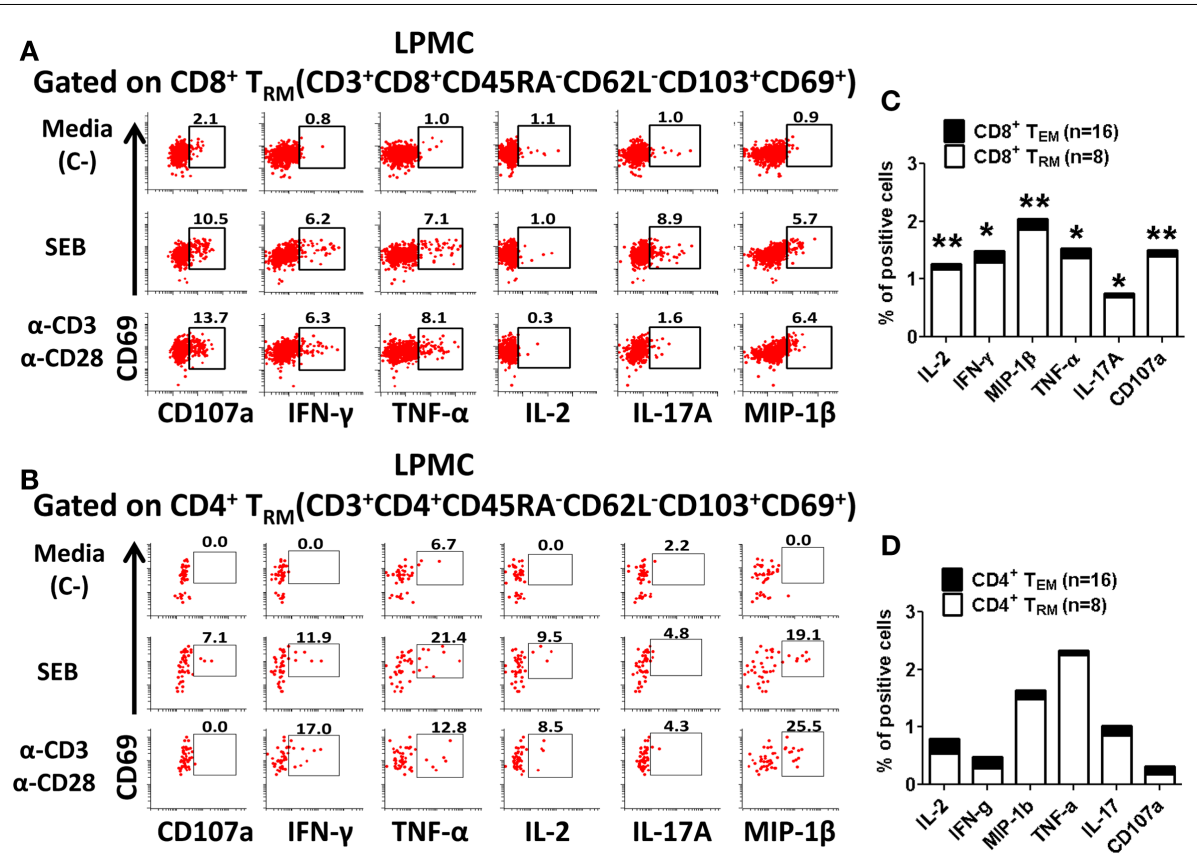

FIGURE 5 | Activation of $\mathrm{CD8}^{+}$and $\mathrm{CD}^{+}$tissue-resident memory $\mathrm{T}$ $\left(T_{\mathrm{RM}}\right)$ cells in gastric LPMC. Representative plot of the activation of gastric $\mathrm{LPMC} \mathrm{CD8}^{+}$(A) or $\mathrm{CD}_{4}^{+}$(B) $\mathrm{T}_{\mathrm{RM}}$ (CD62 $\mathrm{L}^{-} \mathrm{CD} 45 \mathrm{RA} \mathrm{A}^{-} \mathrm{CD} 69^{+}$ CD103 ${ }^{+}$) by two stimulants: (1) staphylococcal enterotoxin B (SEB; $10 \mu \mathrm{g} / \mathrm{ml}$ ) and (2) anti-CD3/CD28 beads ( $\alpha-\mathrm{CD} 3 \alpha-\mathrm{CD} 28)$ to produce IL-2, IFN- $\gamma$, MIP-1 $\beta$, TNF- $\alpha$, IL-17A, and up-regulation of the expression of
CD107a. Cells left unstimulated were used as negative control (Media, C-). Cumulative data comparing baseline activation levels of gastric $\mathrm{LPMC} \mathrm{CD8}^{+}$(C) and $\mathrm{CD}^{+}$(D) $\mathrm{T}_{\mathrm{RM}}$ (white portion of the bar) to PBMC (black portion of the bar). In (C,D) significant differences between $T_{E M}$ and $\mathrm{T}_{\mathrm{RM}}$ are indicated with asterisks on top of each bar; ${ }^{*} p<0.05$; ${ }^{*} p<0.005 ;{ }^{* *} p<0.0005$. the diagnostic pathology reports allowed us to explore whether the higher baseline cytokines levels of $\mathrm{CD}^{+}$and $\mathrm{CD} 4^{+} \mathrm{T}_{\mathrm{RM}}$ cells were due to extrinsic factors causing inflammation of the antral mucosa. Volunteers were classified as having either normal or mildly inflamed (mild diffuse erythema, mild diffuse inflammation, reactive changes) antral mucosa and the baseline cytokines levels were compared between these two groups (Figure S2 in Supplementary Material). There were no differences between the normal and "mild inflammation" groups for any of the cytokines/chemokines (IL-2, IFN $\gamma$, MIP-1 $\beta$, TNF $\alpha$, and IL-17A) and CD107a at baseline in $\mathrm{CD}^{+} \mathrm{T}_{\mathrm{RM}}$ cells (Figure S2 in Supplementary Material). Although $\mathrm{CD}^{+}{ }^{+} \mathrm{T}_{\mathrm{RM}}$ cells showed somewhat increased baseline cytokines levels (IL-2, IFN $\gamma$, TNF $\alpha$, and IL-17A) in the "mild inflammation" group, they were not statistically different than those observed in the normal group (Figure S2 in Supplementary Material).

Gastric $\mathrm{CD} 8^{+} \mathrm{T}_{\mathrm{RM}}$ and CD4 ${ }^{+} \mathrm{T}_{\mathrm{RM}}$ cells from adult volunteers stimulated with mitogens (SEB and anti-CD3/CD28) produced most of the assessed cytokines at higher levels than media control cells (Figures 5A,B; Tables 1-4). In general, higher percentages were observed in gastric $\mathrm{CD} 8^{+} \mathrm{T}_{\mathrm{RM}}$ and $\mathrm{CD} 4{ }^{+} \mathrm{T}_{\mathrm{RM}}$ cells producing cytokines and expressing CD107a than in $\mathrm{CD}^{+} \mathrm{T}_{\mathrm{EM}}$ and $\mathrm{CD} 4{ }^{+} \mathrm{T}_{\mathrm{EM}}$ cells. In some instances, the cytokine production differences were statistically significant (Tables 1 and 2). Overall, results were similar in all age groups (Tables 1 and 2).

We next compared cytokine production by adults, children, and the elderly in both PBMC and LPMC populations (results are summarized in Table 3 ). $\mathrm{CD}^{+} \mathrm{T}_{\mathrm{EM}}$ cells from children did not show statistically significant differences when compared to adults for any of the cytokines evaluated or CD107a expression. In contrast the elderly group demonstrated significantly higher number of $\mathrm{CD}^{+} \mathrm{T}_{\mathrm{EM}}$ cells $(p<0.05)$ producing MIP-1 $\beta$ at baseline levels (compared to adults) and this cytokine was identified in a higher percentage of cells following stimulation (Table 3). Other cytokines observed in a higher percentage of cells following stimulation in the elderly were TNF- $\alpha$ (anti-CD3/CD28) and CD107a expression (SEB and anti-CD3/CD28) (Table 3). In children, a significantly higher percentage of $\mathrm{CD}^{+} \mathrm{T}_{\mathrm{RM}}$ cells (LPMC) expressed CD107a at baseline than in adults (Table 3). Neither children nor the elderly showed differences in the percentage of $\mathrm{CD}^{+}{ }^{+} \mathrm{T}_{\mathrm{EM}}$ cells (PBMC) producing cytokines compared to adults. On the other hand, in children, at baseline, the percentage of CD4 ${ }^{+} \mathrm{T}_{\mathrm{RM}}$ cells (LPMC) producing IFN- $\gamma$ and TNF- $\alpha$ was higher than in adults. However, no differences were noted following stimulation (Table 3). In the elderly, the percentage of CD4 ${ }^{+} \mathrm{T}_{\mathrm{RM}}$ cells producing TNF- $\alpha$, at basal levels were also significantly higher than in adults. Moreover, the percentage of $\mathrm{CD} 4^{+} \mathrm{T}_{\mathrm{RM}}$ cells producing significantly higher levels of IL-2 (anti-CD3/CD28), IFN- $\gamma$ (antiCD3/CD28), and TNF- $\alpha$ (SEB and anti-CD3/CD28) following stimulation was also enhanced (Table 3 ).

We also compared the percentage of cells producing cytokines following SEB and anti-CD3/CD28 stimulation to the control cells in all age groups. The results are summarized in Table 4 . SEB and anti-CD3/CD28 beads efficiently induced CD8 ${ }^{+} \mathrm{T}_{\mathrm{EM}}$ and $\mathrm{CD} 4{ }^{+}$ $\mathrm{T}_{\mathrm{EM}}$ cells from adults and the elderly to produce cytokines and 
Table 1 | Comparison of PBMC CD8 ${ }^{+} \mathrm{T}_{\mathrm{EM}}$ and gastric LPMC CD8 ${ }^{+} \mathrm{T}_{\mathrm{RM}}$ cells activation responses in adult, children, and the elderly

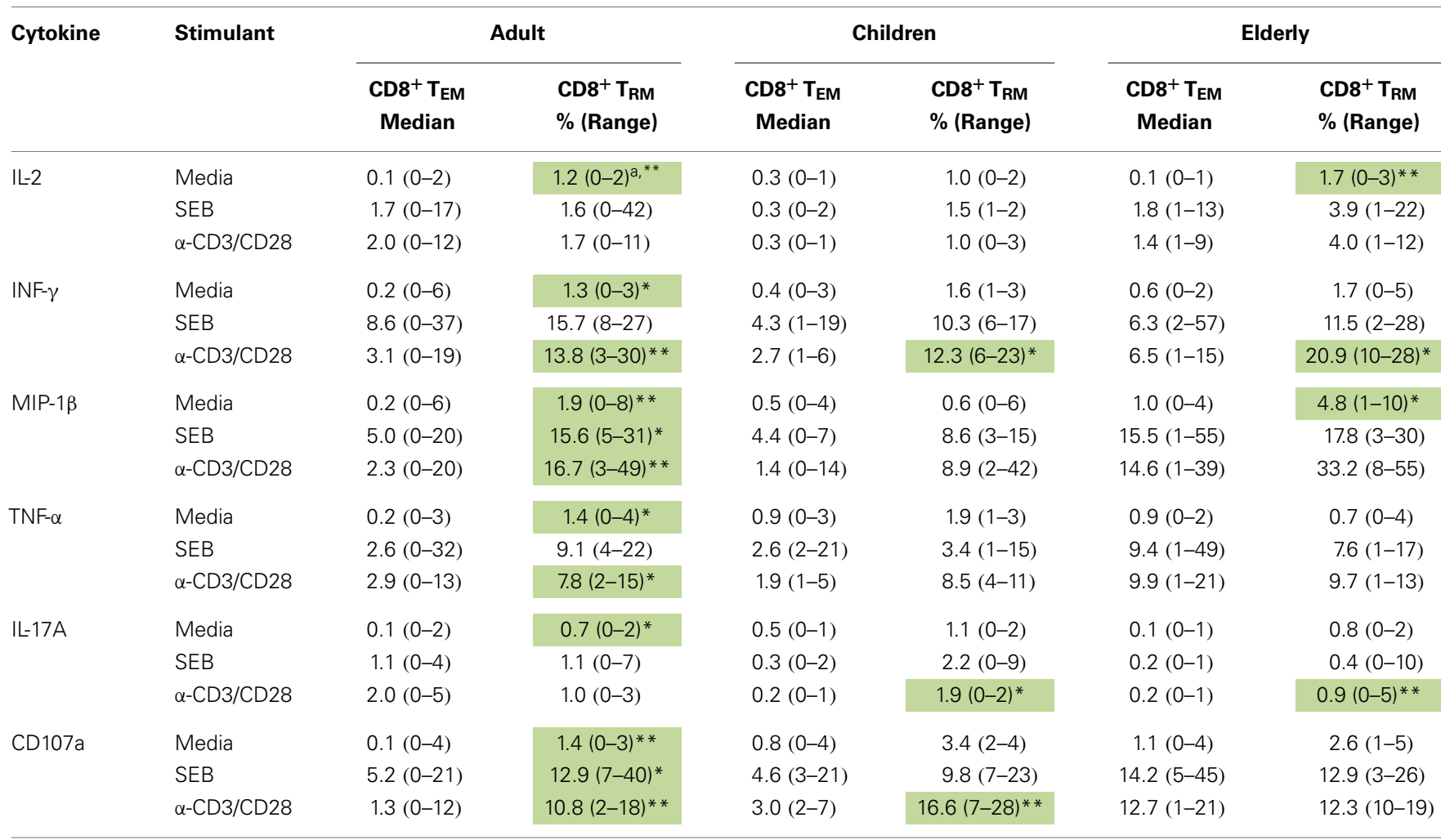

Gastric LPMC CD8 ${ }^{+} T_{R M}$ responses (IL-2, IFN- $\gamma, M I P-1 \beta, T N F-\alpha, I L-17 A$, and CD107a) to two stimulants (SEB and $\alpha-C D 3 / C D 28$ beads) were compared to PBMC CD8+ $T_{E M}$ responses obtained from adults, children, and the elderly. Significant differences are shown in highlighted colors as determined by Mann-Whitney tests. Adults: $n=10$; children: $n=10$; elderly: $n=10$

${ }^{a}$ Light green color = significant increase in the frequency of $C D 8^{+} T_{R M}(L P M C)$ compared to CD8+ $T_{E M}(P B M C) ;{ }^{*} p<0.05 ; *{ }^{*} p<0.005$

CD107a expression compared to media control (Table 4). Interestingly, even though both stimulants induced $\mathrm{CD}^{+} \mathrm{T}_{\mathrm{EM}}$ cells to produce cytokines in children (Table 1), the results were not statistically significant as compared to media (Table 4), and only CD107a up-regulation was significantly induced by SEB in children. SEB and anti-CD3/CD28 beads were unable to stimulate $\mathrm{CD}^{+} \mathrm{T}_{\mathrm{RM}}$ cells to produce IL-17A in any of the three age groups and IL-2 was significantly induced only in the elderly (Table 4). $\mathrm{CD}^{+} \mathrm{T}_{\mathrm{RM}}$ cells were efficiently induced to produce IFN- $\gamma$ and CD107a expression in all three age groups by both SEB and antiCD3/CD28 beads $(p<0.05)$. Furthermore, MIP-1 $\beta$ was efficiently induced in adults and the elderly, but not in children by both stimulants. TNF- $\alpha$ was also significantly induced in all three age groups but only by anti-CD3/CD28 beads. Neither SEB nor anti$\mathrm{CD} 3 / \mathrm{CD} 28$ beads were able to increase the percentage of $\mathrm{CD}^{+}$ $\mathrm{T}_{\mathrm{RM}}$ cells producing IL- 2 , MIP- $1 \beta$, and expressing CD107a in children and IL-17A in adults. However, at least one of these stimulants was able to stimulate CD4 ${ }^{+} \mathrm{T}_{\mathrm{RM}}$ to produce IL-2, IFN- $\gamma$, MIP- $1 \beta$, TNF- $\alpha$, and CD107a in adults and the elderly (Table 4).

\section{MULTIFUNCTIONAL GASTRIC CD8 ${ }^{+}$AND CD4 $^{+}{ }^{+} T_{\text {RM/EM }}$}

$\mathrm{CD}^{+}$and $\mathrm{CD}^{+}{ }^{+} \mathrm{T}$ cells that produce two or more cytokines simultaneously (multifunctional) have enhanced functionality and are more likely to correlate with protection from disease when compared to single cytokine-producing cells (25-28). The induction of multifunctional cells in the human gastric mucosa has not yet been reported and whether these cells play a role in the development or resolution of pathogenesis remains unknown. Thus, we investigated whether $\mathrm{CD} 4^{+}$and $\mathrm{CD} 8^{+} \mathrm{T}_{\mathrm{RM}}$ (LPMC) obtained from the three age groups had multifunctional properties following SEB stimulation. All possible combinations (64 in total) for five cytokines (IFN- $\gamma$, TNF- $\alpha$, IL-2, IL-17A, MIP-1 $\beta$ ) and expression of CD107a were analyzed in multidimensional space using the WinList FCOM function. Similar analyses were performed in CD4 ${ }^{+}$ $\mathrm{T}_{\mathrm{EM}}$ and $\mathrm{CD}^{+} \mathrm{T}_{\mathrm{EM}}$ (PBMC) populations. The results demonstrated that stimulation elicits multifunctional responses in gastric $\mathrm{CD}^{+}{ }^{+} \mathrm{T}_{\mathrm{RM}}$ and $\mathrm{CD} 8^{+} \mathrm{T}_{\mathrm{RM}}$ cells. Similarly, $\mathrm{CD} 4^{+} \mathrm{T}_{\mathrm{EM}}$ and $\mathrm{CD} 8^{+}$ $\mathrm{T}_{\mathrm{EM}}$ cells demonstrated multifunctionality, which is consistent with previous results from our group as well as others (Figures 6 and 7$)(6,24,25,29)$. For simplicity, shown are only the six highest expressing multifunctional CD8 ${ }^{+} \mathrm{T}_{\mathrm{RM}}$ and $\mathrm{CD} 8^{+} \mathrm{T}_{\mathrm{EM}}$ cell groups (Figures 6A,B). Double, triple, quadruple, and quintuple cytokine secreting cells $\mathrm{CD} 8^{+} \mathrm{T}_{\mathrm{RM}}$ and $\mathrm{CD} 8^{+} \mathrm{T}_{\mathrm{EM}}$ were found in all age groups albeit at different percentages. Interestingly, of the six highest multifunctional groups in gastric $\mathrm{CD} 8^{+} \mathrm{T}_{\mathrm{RM}}$ cells, four were also found in CD8 ${ }^{+} \mathrm{T}_{\mathrm{EM}}$ cells (dotted boxes) (Figures 6A,B). We then compared the magnitude of multifunctional $\mathrm{T}$ cells between the age groups and identified some differences. A significantly 
Table 2 | Comparison of PBMC CD4 ${ }^{+} \mathrm{T}_{\mathrm{EM}}$ and gastric $\mathrm{CD4}^{+} \mathrm{T}_{\mathrm{RM}}$ cells activation responses in adult, children, and the elderly

\begin{tabular}{|c|c|c|c|c|c|c|c|}
\hline \multirow[t]{2}{*}{ Cytokine } & \multirow[t]{2}{*}{ Stimulant } & \multicolumn{2}{|c|}{ Adult } & \multicolumn{2}{|c|}{ Children } & \multicolumn{2}{|c|}{ Elderly } \\
\hline & & $\begin{array}{c}\text { CD4 }^{+} \text {TEM }_{\text {EM }} \\
\text { Median }\end{array}$ & $\begin{array}{l}\mathrm{CD}^{+} \mathrm{T}_{\mathrm{RM}} \\
\% \text { (Range) }\end{array}$ & $\begin{array}{c}\text { CD4 }^{+} \mathrm{T}_{\mathrm{EM}} \\
\text { Median }\end{array}$ & $\begin{array}{l}\mathrm{CD4}^{+} \mathrm{T}_{\mathrm{RM}} \\
\% \text { (Range) }\end{array}$ & $\begin{array}{c}\mathrm{CD}^{+} \mathrm{T}_{\mathrm{EM}} \\
\text { Median }\end{array}$ & $\begin{array}{l}\mathrm{CD}^{+} \mathrm{T}_{\mathrm{RM}} \\
\% \text { (Range) }\end{array}$ \\
\hline \multirow[t]{3}{*}{$\mathrm{IL}-2$} & Media & $0.3(0-3)$ & $0.5(0-2)$ & $0.5(0-2)$ & $1.3(0-3)$ & $0.3(0-4)$ & $1.6(0-9)$ \\
\hline & SEB & $2.5(0-60)$ & $3.4(0-35)$ & $1.5(1-5)$ & $0(0-6)$ & $14.8(1-31)$ & $8.7(0-32)$ \\
\hline & $\alpha-C D 3 / C D 28$ & $2.2(0-38)$ & $8.9(0-21)$ & $1.2(0-6)$ & $8.8(0-20)$ & $7.9(3-27)$ & $21.4(5-32)$ \\
\hline \multirow[t]{3}{*}{ INF- $\gamma$} & Media & $0.2(0-2)$ & $0.3(0-2)$ & $0.7(0-3)$ & $4.8(0-9)$ & $0.6(0-3)$ & $0.0(0-5)$ \\
\hline & SEB & $3.0(0-15)$ & $7.0(0-11)$ & $5.8(2-9)$ & 3.7 (0-25) & $6.2(3-18)$ & $3.6(1-19)$ \\
\hline & $\alpha-C D 3 / C D 28$ & $0.6(0-5)$ & $5.6(5-22)^{a, * * *}$ & $4.1(1-9)$ & $10.9(2-25)$ & $3.8(1-14)$ & $14.1(2-27)$ \\
\hline \multirow[t]{3}{*}{ MIP-1 $\beta$} & Media & $0.2(0-1)$ & $1.5(0-8)$ & $0.3(0-2)$ & $4.7(0-6)$ & $0.7(0-1)$ & $1.3(0-8)$ \\
\hline & SEB & $1.5(0-13)$ & $4.8(-33)$ & $0.8(0-5)$ & $11.4(0-35)$ & $1.5(1-3)$ & $13.5(1-21)^{*}$ \\
\hline & $\alpha-C D 3 / C D 28$ & $0.8(0-9)$ & $9.2(1-38)^{* *}$ & $0.3(0-3)$ & $15.0(0-31)$ & $1.2(0-3)$ & $0.0 .3(7-34)^{* * *}$ \\
\hline \multirow[t]{3}{*}{ TNF- $\alpha$} & Media & $0.1(0-3)$ & $2.3(0-6)$ & $1.2(0-6)$ & $4.2(1-6)$ & $2.8(0-5)$ & $1.2(0-6)$ \\
\hline & SEB & $0.9(0-55)$ & $10.8(2-30)$ & $15.7(5-21)$ & $6.3(2-14)$ & $41.1(1-53)$ & $9.9(0-21)^{b, *}$ \\
\hline & $\alpha-C D 3 / C D 28$ & $0.6(24)$ & $5.8(14-42)^{* * *}$ & $12.2(5-25)$ & $24.6(8-60)$ & $23.7(2-31)$ & 27.6 (4-33) \\
\hline \multirow[t]{3}{*}{ IL-17A } & Media & $0.2(0-2)$ & $0.9(0-3)$ & $0.3(0-3)$ & $1.4(0-3)$ & $0.3(0-1)$ & $0.0(0-3)$ \\
\hline & SEB & $2.1(1-16)$ & $2.4(0-12)$ & $3.1(0-7)$ & $6.3(2-25)$ & $1.5(1-3)$ & $2.1(1-9)$ \\
\hline & $\alpha-\mathrm{C03/CD28}$ & $3.8(0-14)$ & $4.8(0-12)$ & $1.6(1-5)$ & $14.1(3-19)^{*}$ & $0.9(0-2)$ & $2.9(0-14)$ \\
\hline \multirow[t]{3}{*}{ CD107a } & Media & $0.2(0-1)$ & $0.2(0-3)$ & $0.3(0-1)$ & $1.3(0-5)$ & $0.2(0-2)$ & $0.0(0-1)$ \\
\hline & SEB & $1.5(1-7)$ & $4.0(0-11)$ & $1.2(0-3)$ & $5.7(2-19)^{*}$ & $1.6(1-3)$ & $2.2(0-11)$ \\
\hline & $\alpha-\mathrm{C} 03 / \mathrm{C} 028$ & $0.7(0-3)$ & $5.9(0-8)^{*}$ & $0.7(0-2)$ & $6.3(2-12)^{*}$ & $1.4(0-3)$ & $3.5(0-12)$ \\
\hline
\end{tabular}

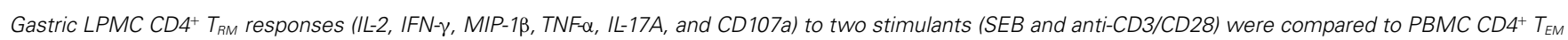
responses obtained from adults, children, and the elderly. Significant differences are shown in highlighted colors as determined by Mann-Whitney tests. Adults: $n=10$; children: $n=10$; elderly: $n=10$.

${ }^{a}$ Light green color $=$ significant increase in the frequency of $C D 4^{+} T_{R M}(L P M C)$ compared to CD4 $4_{E M}(P B M C)$.

${ }^{b}$ Light blue color = significant decrease in the frequency of $C D 4^{+} T_{R M}(L P M C)$ compared to CD4+ $T_{E M}(P B M C) ;{ }^{*} p<0.05 ; *{ }^{*} p<0.005 ; * * * p<0.0005$.

higher percentage of $\mathrm{CD} 8^{+} \mathrm{T}_{\mathrm{RM}}$ cells from the elderly contained double (CD107a $\mathrm{a}^{+}$MIP-1 $\left.\beta^{+}\right)$cytokine-producing cells than adults and children (Figure 6A). Similarly, quintuple (CD107a ${ }^{+}$IFN- $\gamma^{+}$ TNF- $\alpha^{+}$IL- $2^{+}$MIP- $\left.1 \beta^{+}\right)$cytokine-producing cells in the elderly were significantly more abundant than in adults (Figure 6A). In peripheral blood, differences between the age groups within the multi-cytokine-producing sets were also noted. The percentage of double (TNF- $\alpha^{+}$IL- $\left.2^{+}\right)$and triple $\left(\mathrm{IFN}-\gamma^{+}\right.$TNF- $\alpha^{+}$IL- $2^{+}$, as well as CD107a ${ }^{+}$IFN- $\gamma^{+}$MIP- $\left.1 \beta^{+}\right) \mathrm{CD}^{+} \mathrm{T}_{\mathrm{EM}}$ cells in the elderly group was significantly higher than in children (Figure 6B). Furthermore, the percentage of triple $\left(\mathrm{CD} 107 \mathrm{a}^{+}\right.$IFN $-\gamma^{+}$MIP$\left.1 \beta^{+}\right) \mathrm{CD}^{+} \mathrm{T}_{\mathrm{EM}}$ cells was higher in the elderly than in adults (Figure 6B).

We also assessed multifunctionality in $\mathrm{CD} 4^{+} \mathrm{T}_{\mathrm{RM}}$ and $\mathrm{CD} 4^{+}$ $\mathrm{T}_{\mathrm{EM}}$ cells (Figure 7). Both of these cell populations have the potential to become multifunctional and showed differences in the age groups within various multifunctional sets. Of the six highest multifunctional populations in gastric $\mathrm{CD} 4^{+} \mathrm{T}_{\mathrm{RM}}$ cells (LPMC), only two were also found in CD4 ${ }^{+} \mathrm{T}_{\mathrm{EM}}$ cells (PBMC) (dotted boxes) (Figures 7A,B). Double and quadruple cytokine-producing cells were observed in gastric CD4 ${ }^{+} \mathrm{T}_{\mathrm{RM}}$ cells. The percentage of dual producer cells (TNF- $\alpha^{+}$IL-2 ${ }^{+}$and IL- $2^{+}$MIP- $1 \beta^{+}$) in the elderly was significantly higher than in children (Figure 7A). Moreover, the percentage of gastric $\mathrm{CD} 4^{+} \mathrm{T}_{\mathrm{RM}}$ cells producing IL-2 and MIP$1 \beta$ in elderly volunteers was also higher than in adults (Figure 7A). Interestingly, the percentage of dual producer $\mathrm{CD} 4{ }^{+} \mathrm{T}_{\mathrm{RM}}$ cells consisting of IL-17 (CD107a ${ }^{+}$IL-17A ${ }^{+}$and TNF- $\alpha^{+}$IL-17A $^{+}$) in children was significantly higher than adults and the elderly (Figure 7A). Similarly, PBMC CD4 ${ }^{+} \mathrm{T}_{\mathrm{EM}}$ stimulated with SEB display activated cells that contained double, triple, and quadruple cytokine-producing cells (Figure 7B). In the elderly, a significantly higher percentage of $\mathrm{CD} 4^{+} \mathrm{T}_{\mathrm{EM}}$ cells produced double (IFN$\gamma^{+}$TNF- $\alpha^{+}$or TNF- $\alpha^{+}$IL- $\left.^{+}\right)$, triple (CD107a ${ }^{+} \mathrm{IL}_{-} 2^{+}$TNF- $\alpha^{+}$ and IFN- $\gamma^{+}$TNF- $\alpha^{+}$IL-2 ${ }^{+}$), and quadruple (IFN- $\gamma^{+}$TNF- $\alpha^{+}$ IL-2 ${ }^{+}$MIP- $\left.1 \beta^{+}\right)$cytokines than children and adult volunteers (Figure 7B).

\section{DISCUSSION}

Recent reports have described the presence of $\mathrm{T}_{\mathrm{RM}}$ cells $\left(\mathrm{CD}^{+}\right)$ in mucosal surfaces $(4-6,9)$. These cells, originally described in the mouse model, were very recently identified in the lungs of humans (9), along with $\mathrm{CD}^{+}{ }^{+} \mathrm{T}_{\mathrm{RM}}$ cells, which have been less well characterized. In the stomach mucosa, several immune cells have been described and although different methodologies for isolation of mononuclear cells from biopsies have been reported, the optimal conditions remain largely undefined. In this manuscript, 
Table 3 | Summary of gastric LPMCT $\mathrm{RM}_{\mathrm{RM}}$ cells and PBMC $\mathrm{TEM}_{\mathrm{ED}}\left(\mathrm{CD4}^{+}\right.$and $\left.\mathrm{CD}^{+}\right)$responses between children and the elderly to adults.

\begin{tabular}{|c|c|c|c|c|c|c|c|c|c|}
\hline \multirow[t]{2}{*}{ Cytokine } & \multirow[t]{2}{*}{ Stim } & \multicolumn{2}{|c|}{$\begin{array}{c}\text { PBMC } \\
\text { CD8 }^{+} \mathrm{T}_{\mathrm{EM}}\end{array}$} & \multicolumn{2}{|c|}{$\begin{array}{c}\text { LPMC } \\
\text { CDS }^{+} T_{R M}\end{array}$} & \multicolumn{2}{|c|}{$\begin{array}{c}\text { PBMC } \\
\mathrm{CD4}^{+} \mathrm{T}_{\mathrm{EM}}\end{array}$} & \multicolumn{2}{|c|}{$\begin{array}{c}\text { LPMC } \\
\mathrm{CD4}^{+} \mathrm{T}_{\mathrm{RM}}\end{array}$} \\
\hline & & $\mathrm{Ch}^{\mathrm{a}}$ & $E I^{b}$ & Ch & El & Ch & EI & Ch & El \\
\hline \multirow[t]{3}{*}{ IL-2 } & Med & & & & & & & & \\
\hline & SEB & & & & & & & & \\
\hline & $\alpha-C D 3 / C D 28^{c}$ & & & & & & & & $*$ \\
\hline \multirow[t]{3}{*}{$\mathrm{IFN}-\gamma$} & Med & & & & & & & * & \\
\hline & SEB & & & & & & & & \\
\hline & $\alpha-C D 3 / C D 28$ & & & & & & & & * \\
\hline \multirow[t]{3}{*}{ MIP-1 $\beta$} & Med & & $*, d$ & & & & & & \\
\hline & SEB & & $*$ & & & & & & \\
\hline & $\alpha-C D 3 / C D 28$ & & * & & & & & & \\
\hline \multirow[t]{3}{*}{ TNF- $\alpha$} & Med & & & & & & & * & * \\
\hline & SEB & & & & & & & & ** \\
\hline & $\alpha-C D 3 / C D 28$ & & * & & & & & & ** \\
\hline \multirow[t]{3}{*}{ IL-17A } & Med & & & & & & & & \\
\hline & SEB & & & & & & & & \\
\hline & $\alpha-C D 3 / C D 28$ & & & & & & & & \\
\hline \multirow[t]{3}{*}{ CD107a } & Med & & & * & & & & & \\
\hline & SEB & & * & & & & & & \\
\hline & $\alpha-C D 3 / C D 28$ & & ** & & & & & & \\
\hline
\end{tabular}

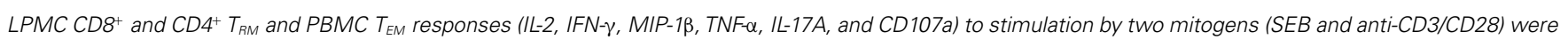

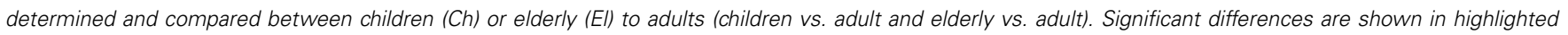

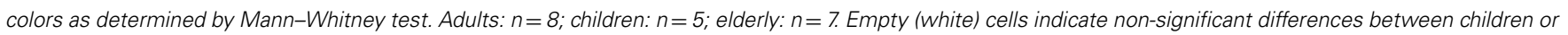
elderly vs. adults as determined by Mann-Whitney tests.

${ }^{a}$ Children; ${ }^{b}$ Elderly; ${ }^{c}$ Anti-CD3/CD28 beads; ${ }^{d}$ Light green color $=$ significant in cytokine production compared to ${ }^{*} p<0.05 ;{ }^{*} p<0.005$.

we report an optimized method for the isolation of human gastric leukocytes from stomach biopsies and, using this method, the identification of $\mathrm{CD}^{+} \mathrm{T}_{\mathrm{RM}}$ and $\mathrm{CD} 4{ }^{+} \mathrm{T}_{\mathrm{RM}}$ cells. Moreover, we explored the ability of these cells to produce cytokines following stimulation with various mitogens, as well as demonstrated the multifunctional nature of these responses. Finally, we investigated whether there are differences in the quality and magnitude of the responses in various age groups.

Our cell isolation protocol (LPMC) from gastric biopsies involved the removal of epithelial cells and a mild enzymatic digestion step (13) that was combined with a mild mechanical disruption step using stainless steel beads (BB). This additional step allowed for maximum dislodgement of cells with minimal damage and provided a more consistent and uniform homogenization, decreasing variation between samples and generating higher viable cell yields. Compared to previously published reports, our method, at a minimum doubled the number of viable LPMC isolated from gastric biopsies $(12,30)$. However, given that biopsies size and weight varies considerably during sampling and that in most studies the biopsy weights have not been reported, the real efficiency of the methods cannot be directly compared. Cell yields expressed as total number of viable cells per milligram of tissue in "dried" biopsies would be optimal to enable this assessment across studies. Interestingly, the number of cells per milligram of tissue in children was higher than in the elderly (Figure 2B). These results were similar to those reported by Bontems et al., who suggested that there was higher cellularity in children than in adults; however, no statistical differences were reported in that study (17). The data from elderly volunteers allowed us to extend the time frame of evaluation and confirmed that as the age of the volunteers increased, the number of mononuclear cells isolated in the stomach decreased.

Consistent with previous reports, the frequency of $\mathrm{CD}^{+}$cells was lower as a percentage of total LPMC cells in the gastric mucosa than in PBMC $(19,31)$. Additionally, $\mathrm{CD}^{+}$and $\mathrm{CD}^{+}{ }^{+} \mathrm{T}$ cells from gastric LPMC were found at similar frequencies as reported by others $(14,16)$ and the vast majority of gastric $\mathrm{CD}^{+}$and $\mathrm{CD}^{+} \mathrm{T}$ cells showed a $\mathrm{T}_{\mathrm{EM}}$ phenotype $\left(\mathrm{CD} 62 \mathrm{~L}^{-}, \mathrm{CD}^{+} 5 \mathrm{RA}^{-}\right)$. These results provide evidence that the optimized cell isolation method described in the present manuscript did not result in cell subset selection bias. Therefore, these cells appeared to be of the newly defined tissue- $\mathrm{T}_{\mathrm{RM}}$ cells in human intestinal tissues (32). This presumption was confirmed by investigating the expression of hallmark receptors for these cells, including CD103 and CD69, which were expressed by $\mathrm{T}$ cells isolated from gastric tissues. Interestingly, differences were noted between $\mathrm{CD}^{+} \mathrm{T}_{\mathrm{RM}}$ and $\mathrm{CD} 4^{+}$ 
Table 4 | Summary of $\mathrm{T}_{\mathrm{RM}}$ and $\mathrm{T}_{\mathrm{EM}}$ responses to stimulation in children, elderly, and adults.

\begin{tabular}{|c|c|c|c|c|c|c|c|c|c|}
\hline \multirow[t]{2}{*}{ Cytokine } & \multirow[t]{2}{*}{ Age } & \multirow{2}{*}{$\begin{array}{c}\text { PBMC } \\
\text { SEB }\end{array}$} & \multirow{2}{*}{$\begin{array}{c}\mathrm{CD8}^{+} \mathrm{T}_{\mathrm{EM}} \\
\alpha \mathbf{3} / 2 \mathbf{8}^{\mathrm{a}}\end{array}$} & \multirow{2}{*}{$\begin{array}{l}\text { LPMC } \\
\text { SEB }\end{array}$} & \multirow{2}{*}{$\begin{array}{c}\mathrm{CD8}^{+} \mathrm{T}_{\mathrm{RM}} \\
\alpha 3 / 28\end{array}$} & \multirow{2}{*}{$\begin{array}{c}\text { PBMC } \\
\text { SEB }\end{array}$} & \multirow{2}{*}{$\begin{array}{c}\mathrm{CD4}^{+} \mathrm{T}_{\mathrm{EM}} \\
\alpha 3 / 28\end{array}$} & \multirow{2}{*}{$\begin{array}{l}\text { LPMC } \\
\text { SEB }\end{array}$} & \multirow{2}{*}{$\begin{array}{c}\mathrm{CD}^{+}{ }^{+} \mathrm{T}_{\mathrm{RM}} \\
\alpha 3 / 28\end{array}$} \\
\hline & & & & & & & & & \\
\hline \multirow[t]{3}{*}{ IL-2 } & $A d^{b}$ & $* *, \mathrm{e}$ & $* *$ & & & $* *$ & * & & $* *$ \\
\hline & $\mathrm{Ch}^{\mathrm{C}}$ & & & & & & & & \\
\hline & $E l^{d}$ & $* * *$ & $* *$ & * & * & $* *$ & * & & * \\
\hline \multirow[t]{3}{*}{ IFN- $\gamma$} & Ad & $* * *$ & $* *$ & $* * *$ & $* * *$ & $* *$ & * & * & $* *$ \\
\hline & $\mathrm{Ch}$ & & & $* *$ & $* *$ & & & & * \\
\hline & El & $* *$ & $* *$ & * & $* *$ & $* *$ & $* *$ & * & $* *$ \\
\hline \multirow[t]{3}{*}{ MIP-1 $\beta$} & $\mathrm{Ad}$ & $* *$ & * & $* *$ & $* * *$ & ** & * & & * \\
\hline & $\mathrm{Ch}$ & & & & & & & & \\
\hline & $\mathrm{El}$ & $* *$ & $* *$ & * & $* *$ & *** & * & * & $* *$ \\
\hline \multirow[t]{3}{*}{ TNF- $\alpha$} & Ad & $* * *$ & $* *$ & $* * *$ & $* * *$ & * & * & $* *$ & $* * *$ \\
\hline & $\mathrm{Ch}$ & & & & $* *$ & * & * & & $* *$ \\
\hline & El & ** & $* *$ & & $* *$ & * & $* *$ & * & $* *$ \\
\hline \multirow[t]{3}{*}{ IL-17A } & Ad & * & * & & & $* *$ & $* *$ & & \\
\hline & $\mathrm{Ch}$ & & & & & & & * & * \\
\hline & El & * & & & & $* *$ & $* *$ & * & \\
\hline \multirow[t]{3}{*}{ CD107a } & Ad & $* * *$ & $* * *$ & $* * *$ & ** & $* * *$ & $* * *$ & * & $* *$ \\
\hline & $\mathrm{Ch}$ & * & & ** & ** & & & & \\
\hline & $\mathrm{El}$ & $* * *$ & $* *$ & $* *$ & $* * *$ & $* *$ & * & $* *$ & \\
\hline
\end{tabular}

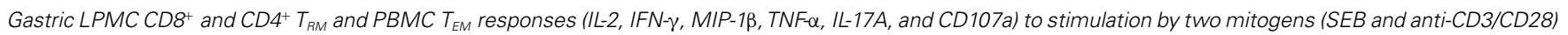

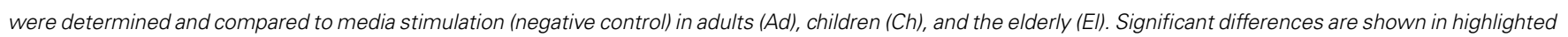

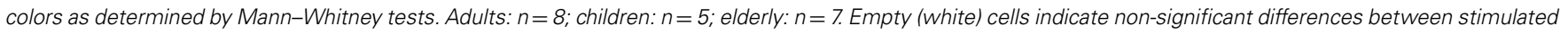
and non-stimulated (media) cultures as determined by Mann-Whitney tests.

${ }^{a}$ Anti-CD3/CD28 beads; ${ }^{b}$ Adults; ${ }^{c}$ Children; ${ }^{d}$ Elderly; ${ }^{e}$ Light green color = significant increase in cytokine production compared to media stimulation, ${ }^{*} p<0.05$; ${ }^{*} p<0.005 ;{ }^{* *} p<0.0005$.

$\mathrm{T}_{\mathrm{RM}}$ cells in gastric tissues. For example, the large majority of $\mathrm{CD}^{+} \mathrm{T}_{\mathrm{RM}}$ cells co-expressed CD103 and CD69, whilst only a small proportion expressed CD103 alone. In contrast, only 35\% of $\mathrm{CD}^{+} \mathrm{T}_{\mathrm{RM}}$ cells co-expressed CD103 and CD69. Therefore, $\mathrm{CD}^{+} \mathrm{T}_{\mathrm{RM}}$ and $\mathrm{CD} 4^{+} \mathrm{T}_{\mathrm{RM}}$ in the human gastric lamina propria exhibited a differential expression pattern of molecules reported to define $\mathrm{T}_{\mathrm{RM}}$ in other human mucosal tissues $(7,8)$. These observations suggest that $\mathrm{CD} 4^{+} \mathrm{T}_{\mathrm{RM}}$ cells are a more heterogeneous and complex population than $\mathrm{CD}^{+} \mathrm{T}_{\mathrm{RM}}$, possibly composed by various subsets. Future studies are necessary to address this important question. Of note, $\mathrm{CD} 4^{+}$and $\mathrm{CD} 8^{+} \mathrm{T}_{\mathrm{RM}}$ were present in children, adult, and the elderly at similar frequencies.

Migration of immune cells from peripheral blood to gut tissues is driven by the expression of tissue-specific homing receptors such as integrin $\alpha 4 \beta 7$ and CCR9 $(33,34)$. Since gastric $T_{R M}$ cells are expected to permanently reside in this tissue, we reasoned that up-regulation of $\mathrm{CD} 103$, which binds to E-cadherin and allows homing at the mucosal level, will result in down-regulation of integrin $\alpha 4 \beta 7$. Consistent with this, $\mathrm{CD} 8^{+} \mathrm{T}_{\mathrm{RM}}$ and $\mathrm{CD} 4^{+} \mathrm{T}_{\mathrm{RM}}$ cells showed a significant down-regulation of integrin $\alpha 4 \beta 7$ compared to its expression levels in $\mathrm{CD} 8^{+} \mathrm{T}_{\mathrm{EM}}$ and $\mathrm{CD} 4^{+} \mathrm{T}_{\mathrm{EM}}$ (PBMC). These results are consistent with data reported in the mouse model in tissues isolated from the small intestine $(32,35)$. Similar results were seen in adults, children, and the elderly. Whether CCR9 is also down-regulated in $\mathrm{CD}^{+}$and $\mathrm{CD} 4^{+} \mathrm{T}_{\mathrm{RM}}$ cells remains to be explored. The fact that we were able to identify $\mathrm{CD} 8^{+} \mathrm{T}_{\mathrm{RM}}$ and $\mathrm{CD}^{+} \mathrm{T}_{\mathrm{RM}}$ cells in LPMC, which contain cells from the lamina propria, suggests that $T_{R M}$ cells are either constantly mobilizing between the epithelial and lamina propria layers of the stomach or reside mainly in the lamina propria layer. In an attempt to address this question, we assessed the IEL fraction in some volunteers and identified mainly $\mathrm{CD}^{+}{ }^{+} \mathrm{T}$ cells, most of which co-expressed CD103 and CD69 (data not shown). CD4 ${ }^{+} \mathrm{T}$ cells were also identified in the IEL fraction, but at such low frequencies that we were unable to ascertain their levels of expression of CD103 and CD69 (data not shown). It is reasonable to speculate that $\mathrm{T}_{\mathrm{RM}}$ cells mainly reside in the lamina propria and once they migrate to the epithelium (i.e., becoming part of the traditional IEL subset) are unable to re-enter the lamina propria. In the latter scenario, $\mathrm{T}_{\mathrm{RM}}$ cells in the lamina propria will constantly supply cells that migrate to the epithelial layer. This would require a change in expression of homing markers and would suggest that, in addition to CD103, other receptor(s) yet to be identified is(are) involved in the homing of these cells from the lamina propria to the epithelium. At this time our data are unable to determine which of these hypotheses is correct. However, it is likely that $\mathrm{T}_{\mathrm{RM}}$ cells shuttle between these 


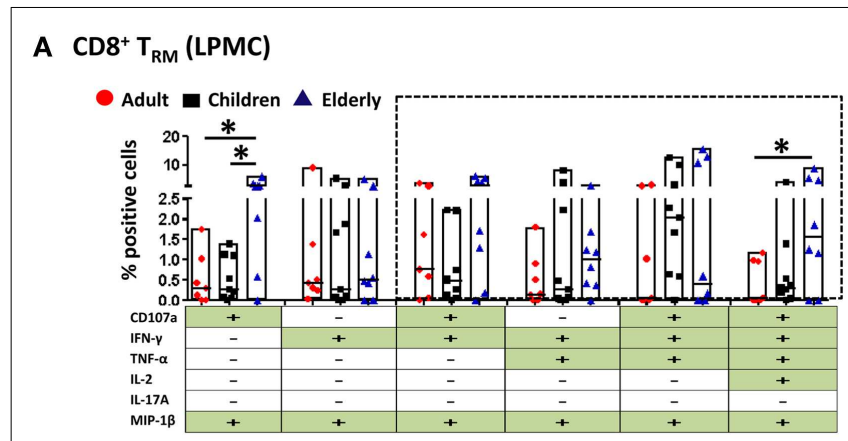

B $\mathrm{CD}^{+} \mathrm{T}_{\mathrm{EM}}$ (PBMC)

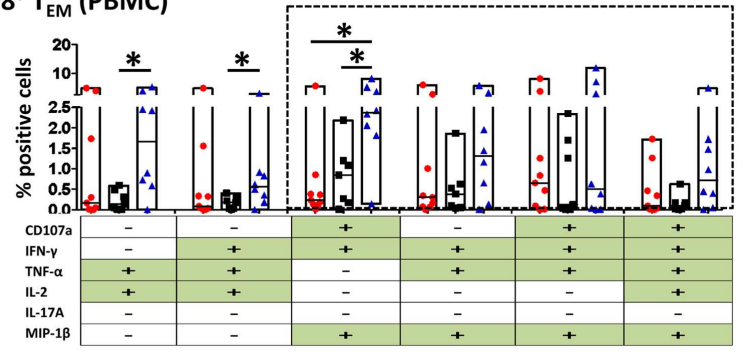

$* \mathrm{P}<0.05$

FIGURE 6 | Multifunctional gastric LPMC CD8 ${ }^{+} \mathrm{T}_{\mathrm{RM}}$ and PBMC $\mathrm{CDB}^{+} \mathrm{T}_{\mathrm{EM}}$ responses to SEB stimulation in adults, children, and the elderly. Multifunctionality was determined by simultaneous detection of two or more functions performed by $C D 8^{+} T_{R M}$ (LPMC) or $\mathrm{CD}^{+} \mathrm{T}_{\mathrm{EM}}$ (PBMC). Six functions were evaluated: production of five cytokines/chemokines (IFN- $\gamma$, TNF- $\alpha$, IL-2, IL-17A, MIP-1 $\beta$ ) and expression of CD107a in response to SEB stimulation. (A) Scatter plot showing the six predominant function patterns in LPMC CD8 ${ }^{+}$ $T_{R M}$ and (B) in PBMC CD8 ${ }^{+} T_{E M}$ cells from adults (red circles, $n=9$ ), children (black squares, $n=7$ ), and the elderly (blue triangles, $n=8$ ). Multifunctionality was analyzed using the FCOM feature of WinList. Significant differences between age groups were denoted by asterisks $\left({ }^{*} p<0.05\right)$. Black dotted boxes indicate the same multiple cytokine-producing cells in LPMC and PBMC $C D 8^{+} \mathrm{T}$ subsets.

two compartments working as sentinel cells and when a specific antigen is encountered, these cells are rapidly activated, producing cytokines and acquiring CTL activity.

$\mathrm{CD}^{+} \mathrm{T}_{\mathrm{RM}}$ cells have been described in mice as well as humans, and reactivity of these cells to antigens derived from pathogens has been demonstrated $(4-6,9)$. We identified $\mathrm{CD}^{+} \mathrm{T}_{\mathrm{RM}}$ and $\mathrm{CD}^{+}{ }^{+} \mathrm{T}_{\mathrm{RM}}$ cell in the stomach of volunteers confirmed to be $H$. pylori negative (as determined by CLO test) (36). While $H$. pylori is well recognized for its role in the development of gastritis, peptic ulcer, and adenocarcinoma, it does not affect the composition of the gastric community (37). The gastric microbiota has been shown to contain a diverse community of 128 phylotypes (37), which could provide the underlying $\mathrm{T}$ cells with antigen(s) to regulate their development. It can be speculated that unidentified infectious agents or the gastric microbiota, through conserved epitopes that resemble those of pathogens, play a role in the development of $\mathrm{T}_{\mathrm{RM}}$ cells (38). Whichever the event(s) that triggers their development, it appears that they occur at a young age, since even the youngest children evaluated in our

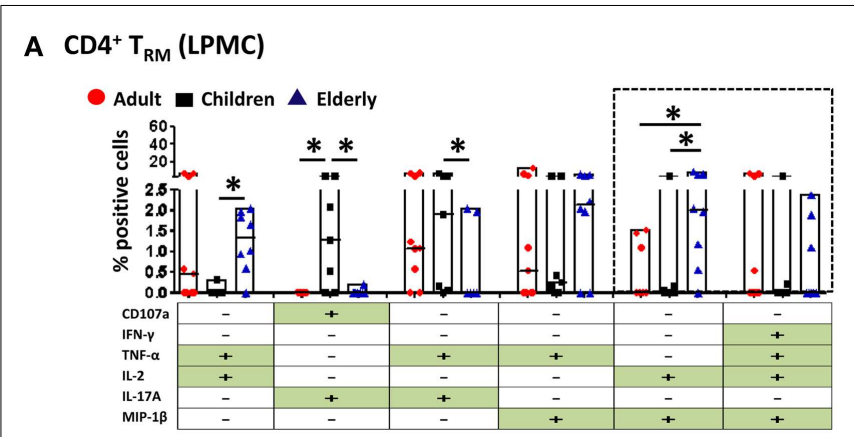

B $\mathrm{CD}^{+} \mathrm{T}_{\mathrm{EM}}$ (PBMC)

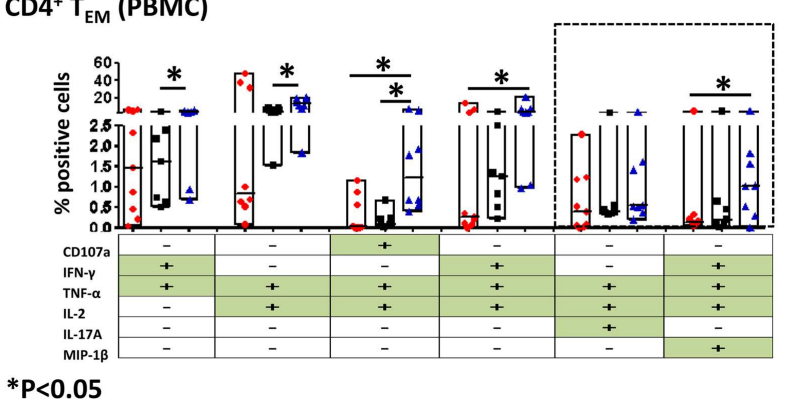

FIGURE 7 | Multifunctional gastric LPMC $\mathrm{CD}^{+} \mathbf{T}_{\mathrm{RM}}$ and PBMC $\mathrm{CD4}^{+} \mathrm{T}_{\mathrm{EM}}$ responses to SEB stimulation in adults, children, and the elderly. Multifunctionality was determined by simultaneous detection of two or more functions performed by $C D 4^{+} T_{R M}$ (LPMC) or $\mathrm{CD}^{+} \mathrm{T}_{\mathrm{EM}}$ (PBMC). Six functions were evaluated: production of five cytokines/chemokines (IFN- $\gamma$, TNF- $\alpha$, IL-2, IL-17A, MIP-1 $\beta$ ) and expression of CD107a in response to SEB stimulation. (A) Scatter plot showing the six predominant function patterns in LPMC CD4 ${ }^{+}$ $T_{R M}$ and (B) in PBMC CD4 ${ }^{+} T_{E M}$ cells from adults (red circles, $n=9$ ), children (black squares, $n=7$ ), and the elderly (blue triangles, $n=8$ ). Multifunctionality was analyzed using the FCOM feature of WinList. Significant differences between age groups were denoted by asterisks $\left({ }^{*} p<0.05\right)$. Black dotted boxes indicate the same multiple cytokine-producing cells in LPMC and PBMC CD4 ${ }^{+}$T subsets.

studies (i.e., 7-year-old) showed the presence of these unique cells. Future experiments designed to address these questions will include the investigation of the role of the microbiota in the development of $\mathrm{T}_{\mathrm{RM}}$ cells and a comparison of the cytokine production by $\mathrm{CD}^{+}{ }^{+} \mathrm{T}_{\mathrm{RM}}$ and $\mathrm{CD} 8^{+} \mathrm{T}_{\mathrm{RM}}$ cells from $H$. pylori positive and healthy volunteers following stimulation with $H$. pylori antigens.

Gastric $\mathrm{CD} 8{ }^{+} \mathrm{T}_{\mathrm{RM}}$ and $\mathrm{CD} 4{ }^{+} \mathrm{T}_{\mathrm{RM}}$ cells obtained from biopsies of children, adults, and the elderly were responsive to SEB and antiCD3/CD28 beads stimulations by secreting Th1 cytokines (IL-2, IFN- $\gamma$, TNF- $\alpha$, IL-17A, MIP-1 $\beta$ ) and up-regulating the cytotoxicity marker CD107a. These results confirm and extend studies in which gastric $\mathrm{CD} 4{ }^{+} \mathrm{T}$ cells obtained from healthy adults $(H$. pylori negative) secreted Th 1 cytokines (IFN- $\gamma$ and TNF- $\alpha$ ) when stimulated with PMA/Ionomycin (16,31). Interestingly, $\mathrm{CD} 8^{+} \mathrm{T}_{\mathrm{RM}}$ cells appeared to produce cytokines constitutively; a higher percentage of $\mathrm{T}_{\mathrm{RM}}$ cells cultured in media only showed cytokine production compared to $\mathrm{CD} 8^{+} \mathrm{T}_{\mathrm{EM}}$ cells. Similar results, albeit not statistically significant, were identified in $\mathrm{CD} 4^{+} \mathrm{T}_{\mathrm{RM}}$ cells. These observations 
suggest that $\mathrm{T}_{\mathrm{RM}}$ cells are more prone to activation and possibly have a lower antigenic threshold for stimulation than their peripheral blood counterparts. However, it is important to consider that while the volunteers were $H$. pylori negative, they were referred for EGD due to the presence of clinical symptoms (e.g., dysphagia, heartburn, GERD, etc.). Therefore, to determine if gastric $\mathrm{T}_{\mathrm{RM}}$ cells were activated in response to an inflammatory environment resulting from the underlying clinical condition(s), we stratified the baseline cytokine levels based on the pathology findings from each volunteer (normal and "mild inflammation") (Figure S2 in Supplementary Material). Neither $\mathrm{CD} 8^{+} \mathrm{T}_{\mathrm{RM}}$ nor $\mathrm{CD} 4^{+} \mathrm{T}_{\mathrm{RM}}$ cells showed statistically significant differences between the normal and mild inflammation groups. These results support the idea that $\mathrm{T}_{\mathrm{RM}}$ cells show a persistent activation state in "normal volunteers." An alternative explanation for the persistent activation state of $\mathrm{T}_{\mathrm{RM}}$ cells could involve the role of the gastric microbiota. Thus, future studies should be directed to explore this and other alternative explanations. Whether the higher percentage of cells producing cytokines and up-regulating CD107a spontaneously have a deleterious effect at the gastric mucosal level or that this enhanced inflammatory environment benefits the host by limiting colonization with pathogens remains to be explored. Overall, $\mathrm{CD} 8^{+} \mathrm{T}_{\mathrm{RM}}$ cells from adult, children, and the elderly responded to the stimuli and the cytokine production was higher compared to PBMC, but more evident in adults and elderly than in children.

There is little information on the induction of local immune responses in the gastric mucosa from children $(39,40)$. Few studies have evaluated the cytokine responses in the gastric mucosa of this age group and the results are contradictory $(17,41,42)$. One study found that lower levels of IFN- $\gamma$ were produced in culture supernatants of gastric mucosa tissues from children compared to adults, but no differences in TNF- $\alpha$, IL-2, or IL-10 were detected regardless of their $H$. pylori status (17). On the other hand, a recent study showed that in $H$. pylori infected children, the gastric concentration of IL- $1 \alpha$ and TNF- $\alpha$ were significantly higher than that in infected adults whereas IL-2, IL-12p70, and IFN- $\gamma$ were lower in infected children than in infected adults (42). Of note, differences in cytokine profiles were observed between infected and uninfected individuals in both age groups (42). Epidemiological studies have also suggested that unlike adults, children rarely develop peptic ulcers or gastric atrophy (43-45). This suggests that children may display a unique immunological milieu that limits gastric mucosal damage. In our study, even though the phenotype and abundance of gastric $\mathrm{CD} 8^{+} \mathrm{T}_{\mathrm{RM}}$ and $\mathrm{CD} 4^{+} \mathrm{T}_{\mathrm{RM}}$ in children were similar to those of adults and the elderly, their responses were different. CD4 ${ }^{+} \mathrm{T}_{\mathrm{RM}}$ and $\mathrm{CD} 8^{+} \mathrm{T}_{\mathrm{RM}}$ cells from children responded only moderately to the mitogenic stimulations and secreted lower amounts of cytokines than their adult and the elderly counterparts. Our results are consistent, and markedly extend, previous studies demonstrated that gastric $\mathrm{T}$ cells from children are less responsive to stimulation than adults. Moreover, our results provide novel information on cells isolated from elderly subjects. Additionally, it has been shown that Th1 and Th17 responses in children are down-regulated, resulting in reduced gastritis due to H. pylori infections (46). This observation contrasts with that of adults, in whom $H$. pylori infections usually result in significant inflammation. Furthermore, in children who are positive for $H$. pylori, the levels of regulatory $\mathrm{T}$ cells $\left(\mathrm{T}_{\text {regs }}\right)$ and IL-10 secreting cells in the gastric mucosa are higher than in $H$. pylori infected adults $(46,47)$. Therefore, these observations suggest that in children the regulatory mechanisms at the gastric level are more active than in adults and this could contribute to the limited reactivity identified in $\mathrm{CD}^{+}$and $\mathrm{CD} 8^{+} \mathrm{T}_{\mathrm{RM}}$ cells. Future studies involving the investigation of the presence and functional properties of $\mathrm{T}_{\text {regs }}$ in the gastric mucosa of children as compared to adults/elderly will shed light into this important question.

Multifunctionality analysis following SEB stimulation confirmed that $\mathrm{T}_{\mathrm{RM}}$ are multifunctional and also reinforced the idea that age is a significant factor. Interestingly, various multi-cytokine production patterns demonstrated that in the elderly a higher percentage of cells produced multiple cytokines than in children, suggesting that elderly cells are more reactive to stimulation. This data further confirmed and extend the observations in this manuscript that cells from children are less susceptible to activation. Of note, there were a few instances in which cells from children produced more cytokines than those isolated from the elderly (e.g., $\mathrm{CD}^{+} \mathrm{T}_{\mathrm{RM}}$ dual producers CD107a and IL-17A, as well as TNF- $\alpha$ and IL-17A). This reinforces the indication that cytokine production is age-related.

In summary, we developed a consistent method for isolation of immune cells from the gastric biopsies that increased cell yields and allowed the identification of $\mathrm{CD} 8^{+} \mathrm{T}_{\mathrm{RM}}$ and $\mathrm{CD} 4^{+} \mathrm{T}_{\mathrm{RM}}$ cells in children, adults, and the elderly. We demonstrated that these cells were functional and responsive to various categories of stimulants. Finally, we show that gastric cells of children respond differently to stimuli than adults and the elderly in terms of cytokines and multi-cytokine production suggesting that unique regulatory mechanisms are operative in the children's gastric mucosa.

\section{ACKNOWLEDGMENTS}

We are indebted to the volunteers who allowed us to perform this study. We thank Onyinye Erondu, Robin Barnes, and the staff from the Recruiting Section of Center for Vaccine Development for their help in collecting gastric biopsies and blood specimens and Ms. Regina Harley and Catherine Storrer for excellent technical assistance. This work was supported, in part, by NIAID U19 AI082655 (CCHI) to Marcelo B. Sztein.

\section{SUPPLEMENTARY MATERIAL}

The Supplementary Material for this article can be found online at http://journal.frontiersin.org/Journal/10.3389/fimmu. 2014.00294/abstract

\section{REFERENCES}

1. Sallusto F, Lenig D, Forster R, Lipp M, Lanzavecchia A. Two subsets of memory T lymphocytes with distinct homing potentials and effector functions. Nature (1999) 401:708-12. doi:10.1038/44385

2. Sallusto F, Geginat J, Lanzavecchia A. Central memory and effector memory T cell subsets: function, generation, and maintenance. Annu Rev Immunol (2004) 22:745-63. doi:10.1146/annurev.immunol.22.012703.104702

3. Bevan MJ. Memory T cells as an occupying force. Eur J Immunol (2011) 41:1192-5. doi:10.1002/eji.201041377

4. Sheridan BS, Lefrancois L. Regional and mucosal memory T cells. Nat Immunol (2011) 12:485-91. doi:10.1038/ni.2029

5. Ariotti S, Beltman JB, Chodaczek G, Hoekstra ME, van Beek AE, Gomez-Eerland $\mathrm{R}$, et al. Tissue-resident memory CD8+ T cells continuously patrol skin epithelia 
to quickly recognize local antigen. Proc Natl Acad Sci US A (2012) 109:19739-44. doi:10.1073/pnas.1208927109

6. Gebhardt T, MacKay LK. Local immunity by tissue-resident CD8+ memory T cells. Front Immunol (2012) 3:340. doi:10.3389/fimmu.2012.00340

7. Sathaliyawala T, Kubota M, Yudanin N, Turner D, Camp P, Thome JJ, et al. Distribution and compartmentalization of human circulating and tissue-resident memory T cell subsets. Immunity (2013) 38:187-97. doi:10.1016/j.immuni. 2012.09.020

8. Mackay LK, Rahimpour A, Ma JZ, Collins N, Stock AT, Hafon M-L, et al. The developmental pathway for CD103+CD8+ tissue-resident memory T cells of skin. Nat Immunol (2013) 14:1294-301. doi:10.1038/ni.2744

9. Turner DL, Bickham KL, Thome JJ, Kim CY, D’Ovidio F, Wherry EJ, et al. Lung niches for the generation and maintenance of tissue-resident memory $\mathrm{T}$ cells. Mucosal Immunol (2013) 7(3):501-10. doi:10.1038/mi.2013.67

10. Hatz RA, Meimarakis G, Bayerdorffer E, Stolte M, Kirchner T, Enders G. Characterization of lymphocytic infiltrates in Helicobacter pylori-associated gastritis. Scand J Gastroenterol (1996) 31:222-8. doi:10.3109/00365529609004870

11. Quiding-Jarbrink M, Raghavan S, Sundquist M. Enhanced M1 macrophage polarization in human Helicobacter pylori-associated atrophic gastritis and in vaccinated mice. PLoS One (2010) 5:e15018. doi:10.1371/journal.pone.0015018

12. Bimczok D, Clements RH, Waites KB, Novak L, Eckhoff DE, Mannon PJ, et al. Human primary gastric dendritic cells induce a Th1 response to $H$. pylori. Mucosal Immunol (2010) 3:260-9. doi:10.1038/mi.2010.10

13. Yun CH, Lundgren A, Azem J, Sjoling A, Holmgren J, Svennerholm AM, et al. Natural killer cells and Helicobacter pylori infection: bacterial antigens and interleukin-12 act synergistically to induce gamma interferon production. Infect Immun (2005) 73:1482-90. doi:10.1128/IAI.73.3.1482-1490.2005

14. O'Keeffe J, Gately CM, O’Donoghue Y, Zulquernain SA, Stevens FM, Moran AP. Natural killer cell receptor T-lymphocytes in normal and Helicobacter pyloriinfected human gastric mucosa. Helicobacter (2008) 13:500-5. doi:10.1111/j. 1523-5378.2008.00641.x

15. Mattsson A, Lonroth H, Quiding-Jarbrink M, Svennerholm AM. Induction of B cell responses in the stomach of Helicobacter pylori-infected subjects after oral cholera vaccination. J Clin Invest (1998) 102:51-6. doi:10.1172/JCI22

16. Bamford KB, Fan X, Crowe SE, Leary JF, Gourley WK, Luthra GK, et al. Lymphocytes in the human gastric mucosa during Helicobacter pylori have a Thelper cell 1 phenotype. Gastroenterology (1998) 114:482-92. doi:10.1016/S0016-5085(98) 70531-1

17. Bontems P, Robert F, Van Gossum A, Cadranel S, Mascart F. Helicobacter pylori modulation of gastric and duodenal mucosal T cell cytokine secretions in children compared with adults. Helicobacter (2003) 8:216-26. doi:10.1046/j.15235378.2003.00147.x

18. Smythies LE, Sellers M, Clements RH, Mosteller-Barnum M, Meng G, Benjamin WH, et al. Human intestinal macrophages display profound inflammatory anergy despite avid phagocytic and bacteriocidal activity. J Clin Invest (2005) 115:66-75. doi:10.1172/JCI200519229

19. Goll R, Husebekk A, Isaksen V, Kauric G, Hansen T, Florholmen J. Increased frequency of antral CD4+ T and CD19+ B cells in patients with Helicobacter pylori-related peptic ulcer disease. Scand J Immunol (2005) 61:92-7. doi:10.1111/j.0300-9475.2005.01537.x

20. Satoh Y, Ogawara H, Kawamura O, Kusano M, Murakami H. Clinical significance of peripheral blood $\mathrm{T}$ lymphocyte subsets in Helicobacter pylori-infected patients. Gastroenterol Res Pract (2012) 2012:819842. doi:10.1155/2012/819842

21. Toapanta FR, Bernal PJ, Sztein MB. Diverse phosphorylation patterns of B cell receptor-associated signaling in naïve and memory human B cells revealed by phosphoflow, a powerful technique to study signaling at the single cell level. Front Cell Infect Microbiol (2012) 2:128. doi:10.3389/fcimb.2012.00128

22. Wahid R, Salerno-Goncalves R, Tacket CO, Levine MM, Sztein MB. Generation of specific effector and memory $\mathrm{T}$ cells with gut- and secondary lymphoid tissue-homing potential by oral attenuated CVD 909 typhoid vaccine in humans. Mucosal Immunol (2008) 1:389-98. doi:10.1038/mi.2008.30

23. Betts MR, Koup RA. Detection of T-cell degranulation: CD107a and b. Methods Cell Biol (2004) 75:497-512. doi:10.1016/S0091-679X(04)75020-7

24. Salerno-Goncalves R, Pasetti MF, Sztein MB. Characterization of CD8(+) effector $\mathrm{T}$ cell responses in volunteers immunized with Salmonella enterica serovar typhi strain Ty21a typhoid vaccine. J Immunol (2002) 169:2196-203. doi:10.4049/jimmunol.169.4.2196

25. McArthur MA, Sztein MB. Unexpected heterogeneity of multifunctional T cells in response to superantigen stimulation in humans. Clin Immunol (2013) 146:140-52. doi:10.1016/j.clim.2012.12.003
26. Darrah PA, Patel DT, De Luca PM, Lindsay RW, Davey DF, Flynn BJ, et al. Multifunctional TH1 cells define a correlate of vaccine-mediated protection against Leishmania major. Nat Med (2007) 13:843-50. doi:10.1038/nm1592

27. Kannanganat S, Ibegbu C, Chennareddi L, Robinson HL, Amara RR. Multiple-cytokine-producing antiviral CD4 T cells are functionally superior to single-cytokine-producing cells. J Virol (2007) 81:8468-76. doi:10.1128/JVI. 00228-07

28. Kannanganat S, Kapogiannis BG, Ibegbu C, Chennareddi L, Goepfert P, Robinson HL, et al. Human immunodeficiency virus type 1 controllers but not noncontrollers maintain CD4 T cells coexpressing three cytokines. J Virol (2007) 81:12071-6. doi:10.1128/JVI.01261-07

29. McArthur MA, Sztein MB. Heterogeneity of Multifunctional IL-17A producing S. typhi-specific CD8+ T cells in volunteers following Ty21a typhoid immunization. PLoS One (2012) 7:e38408. doi:10.1371/journal.pone.0038408

30. Mattsson A, Quiding-Jarbrink M, Lonroth H, Hamlet A, Ahlstedt I, Svennerholm A. Antibody-secreting cells in the stomachs of symptomatic and asymptomatic Helicobacter pylori-infected subjects. Infect Immun (1998) 66:2705-12.

31. Caruso R, Fina D, Paoluzi OA, Del Vecchio Blanco G, Stolfi C, Rizzo A, et al. IL-23-mediated regulation of IL-17 production in Helicobacter pyloriinfected gastric mucosa. Eur J Immunol (2008) 38:470-8. doi:10.1002/eji. 200737635

32. Masopust D, Choo D, Vezys V, Wherry EJ, Duraiswamy J, Akondy R, et al. Dynamic T cell migration program provides resident memory within intestinal epithelium. J Exp Med (2010) 207:553-64. doi:10.1084/jem.20090858

33. Iwata M, Hirakiyama A, Eshima Y, Kagechika H, Kato C, Song SY. Retinoic acid imprints gut-homing specificity on T cells. Immunity (2004) 21:527-38. doi:10.1016/j.immuni.2004.08.011

34. Cassani B, Villablanca EJ, Quintana FJ, Love PE, Lacy-Hulbert A, Blaner WS, et al. Gut-tropic T cells that express integrin $\alpha 4 \beta 7$ and CCR9 are required for induction of oral immune tolerance in mice. Gastroenterology (2011) 141:2109-18. doi:10.1053/j.gastro.2011.09.015

35. Zhang N, Bevan MJ. Transforming growth factor- $\beta$ signaling controls the formation and maintenance of gut-resident memory $\mathrm{T}$ cells by regulating migration and retention. Immunity (2013) 39:687-96. doi:10.1016/j.immuni.2013.08. 019

36. Windsor HM, Ho GY, Marshall BJ. Successful recovery of $H$. pylori from rapid urease tests (CLO tests). Am J Gastroenterol (1999) 94:3181-3. doi:10.1111/j. 1572-0241.1999.01515.x

37. Bik EM, Eckburg PB, Gill SR, Nelson KE, Purdom EA, Francois F, et al. Molecular analysis of the bacterial microbiota in the human stomach. Proc Natl Acad Sci U S A (2006) 103:732-7. doi:10.1073/pnas.0506655103

38. Walker MM, Talley NJ. Review article: bacteria and pathogenesis of disease in the upper gastrointestinal tract - beyond the era of Helicobacter pylori. Aliment Pharmacol Ther (2014) 39:767-79. doi:10.1111/apt.12666

39. Muñoz L, Camorlinga M, Hernández R, Giono S, Ramón G, Muñoz O, et al. Immune and proliferative cellular responses to Helicobacter pylori infection in the gastric mucosa of Mexican children. Helicobacter (2007) 12:224-30. doi:10.1111/j.1523-5378.2007.00493.x

40. Lagunes-Servin H, Torres J, Maldonado-Bernal C, érez-Rodríguez MP, HuertaYépez S, Madrazo de la Garza A, et al. Toll-like receptors and cytokines are upregulated during Helicobacter pylori infection in children. Helicobacter (2013) 18:423-32. doi:10.1111/hel.12067

41. Lopes AI, Quiding-Jarbrink M, Palha A, Ruivo J, Monteiro L, Oleastro M, et al. Cytokine expression in pediatric Helicobacter pylori infection. Clin Diagn Lab Immunol (2005) 12:994-1002. doi:10.1128/CDLI.12.8.994-1002.2005

42. Freire de Melo F, Rocha GA, Rocha AM, Teixeira KN, Pedroso SH, Pereira Junior JB, et al. Th1 immune response to $H$. pylori infection varies according to the age of the patients and influences the gastric inflammatory patterns. Int J Med Microbiol (2014) 304:300-6. doi:10.1016/j.ijmm.2013.11.001

43. Torres J, Pérez-Pérez GP, Goodman KJ, Atherton JC, Gold BD, Harris PR, et al. A comprehensive review of the natural history of Helicobacter pylori infection in children. Arch Med Res (2000) 31:431-69. doi:10.1016/S0188-4409(00) 00099-0

44. Poddar U, Yachha SK. Helicobacter pylori in children: an Indian perspective. Indian Pediatr (2007) 44:761-70.

45. Kato S, Nishino Y, Ozawa K, Konno M, Maisawa S-I, Toyoda S, et al. The prevalence of Helicobacter pylori in Japanese children with gastritis or peptic ulcer disease. J Gastroenterol (2004) 39:734-8. doi:10.1007/s00535-004-1381-2

46. Serrano C, Wright SW, Bimczok D, Shaffer CL, Cover TL, Venegas A, et al. Downregulated Th17 responses are associated with reduced gastritis 
in Helicobacter pylori-infected children. Mucosal Immunol (2013) 6:950-9. doi:10.1038/mi.2012.133

47. Harris PR, Serrano CA, Villagrán A, Walker MM, Thomson M, Duarte I, et al. Helicobacter pylori-associated hypochlorhydria in children, and development of iron deficiency. J Clin Pathol (2013) 66:343-7. doi:10.1136/jclinpath-2012201243

Conflict of Interest Statement: The authors declare that the research was conducted in the absence of any commercial or financial relationships that could be construed as a potential conflict of interest.

Received: 18 April 2014; accepted: 05 June 2014; published online: 19 June 2014.
Citation: Booth JS, Toapanta FR, Salerno-Goncalves R, Patil S, Kader HA, Safta AM, Czinn SJ, Greenwald BD and Sztein MB (2014) Characterization and functional properties of gastric tissue-resident memory $T$ cells from children, adults, and the elderly. Front. Immunol. 5:294. doi: 10.3389/fimmu.2014.00294

This article was submitted to Mucosal Immunity, a section of the journal Frontiers in Immunology.

Copyright (๑) 2014 Booth, Toapanta, Salerno-Goncalves, Patil, Kader, Safta, Czinn, Greenwald and Sztein. This is an open-access article distributed under the terms of the Creative Commons Attribution License (CC BY). The use, distribution or reproduction in other forums is permitted, provided the original author(s) or licensor are credited and that the original publication in this journal is cited, in accordance with accepted academic practice. No use, distribution or reproduction is permitted which does not comply with these terms. 